\title{
Fingerprints of changes in the terrestrial carbon cycle in response to large reorganizations in ocean circulation
}

\author{
A. Bozbiyik ${ }^{1,2}$, M. Steinacher ${ }^{1,2}$, F. Joos ${ }^{1,2}$, T. F. Stocker ${ }^{1,2}$, and L. Menviel ${ }^{1,2}$ \\ ${ }^{1}$ Climate and Environmental Physics, University of Bern, Bern, Switzerland \\ ${ }^{2}$ Oeschger Center for Climate Change Research, University of Bern, Bern, Switzerland
}

Received: 27 August 2010 - Published in Clim. Past Discuss.: 23 September 2010

Revised: 28 February 2011 - Accepted: 1 March 2011 - Published: 28 March 2011

\begin{abstract}
CO}_{2}$ and carbon cycle changes in the land, ocean and atmosphere are investigated using the comprehensive carbon cycle-climate model NCAR CSM1.4-carbon. Ensemble simulations are forced with freshwater perturbations applied at the North Atlantic and Southern Ocean deep water formation sites under pre-industrial climate conditions. As a result, the Atlantic Meridional Overturning Circulation reduces in each experiment to varying degrees. The physical climate fields show changes qualitatively in agreement with results documented in the literature, but there is a clear distinction between northern and southern perturbations. Changes in the physical variables, in turn, affect the land and ocean biogeochemical cycles and cause a reduction, or an increase, in the atmospheric $\mathrm{CO}_{2}$ concentration by up to $20 \mathrm{ppmv}$, depending on the location of the perturbation. In the case of a North Atlantic perturbation, the land biosphere reacts with a strong reduction in carbon stocks in some tropical locations and in high northern latitudes. In contrast, land carbon stocks tend to increase in response to a southern perturbation. The ocean is generally a sink of carbon although large reorganizations occur throughout various basins. The response of the land biosphere is strongest in the tropical regions due to a shift of the Intertropical Convergence Zone. The carbon fingerprints of this shift, either to the south or to the north depending on where the freshwater is applied, can be found most clearly in South America. For this reason, a compilation of various paleoclimate proxy records of Younger Dryas precipitation changes are compared with our model results. The proxy records, in general, show good agreement with the model's response to a North Atlantic freshwater perturbation.
\end{abstract}

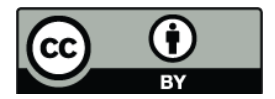

Correspondence to: A. Bozbiyik (bozbiyik@climate.unibe.ch)

\section{Introduction}

Records from various climate proxies, especially Greenland ice cores and sediments from the North Atlantic, suggest that there have been large and abrupt changes in the climate during the last glacial period (Stocker, 2000; Rahmstorf, 2002; Clement and Peterson, 2008). Those transitions occurred on the time scale of a few decades to as little as a few years. The Greenland ice core from North GRIP contains 26 such abrupt warming events with amplitudes locally of up to $16^{\circ} \mathrm{C}$ (NorthGRIP Members, 2004; Huber et al., 2006; Steffensen et al., 2008). These are known as Dansgaard-Oeschger ( $D$ O) events (Dansgaard et al., 1984; Oeschger et al., 1984). There are also accompanying intense cold periods preceding these events which have a corresponding signal in the sediment cores from the northern Atlantic that are marked by distinct layers of ice rafted debris (Heinrich, 1988; Bond et al., 1993; Hemming, 2004). These surges of large amounts of ice into the sea, known as Heinrich events, are associated with some of the coldest temperatures in Greenland. Moreover, high-resolution measurements on Antarctic ice cores indicate that each of the D-O events has a less abrupt counterpart in the south (EPICA Community Members, 2006), likely due to the operation of the bipolar seesaw (Stocker and Johnsen, 2003). The last event in this sequence was the Younger Dryas cold event (12.7-11.6 cal kyr BP) and its termination with an abrupt warming (D-O 0). Signatures of those climate events have also been found in other climate archives, such as the isotopic and pollen records in the lake and marine sediments (Eicher et al., 1981; Ruddiman and McIntyre, 1981; Bond et al., 1993; Yu and Eicher, 1998; Ammann et al., 2000; Baker et al., 2001; Prokopenko et al., 2001; Voelker, 2002; Hughen et al., 2004; Barker et al., 2009) and European and Asian loess records (Ding et al., 1999; Porter, 2001; Rousseau et al., 2002) with a geographic distribution from Europe to Asia and beyond. 
Many of the characteristics of an abrupt climate change event can be simulated by coupled climate models that are perturbed by anomalous freshwater fluxes applied in the North Atlantic (Bryan, 1986; Mikolajewicz, 1996; Schiller et al., 1997; Manabe and Stouffer, 1999; Marchal et al., 1998; Timmermann et al., 2003; Knutti et al., 2004; Zhang and Delworth, 2005; Stocker and Marchal, 2000; Stouffer et al., 2006), which can cause the collapse of the Atlantic Meridional Overturning Circulation (AMOC).

The purpose of this paper is to determine the dependence of the climate and carbon cycle to the freshwater perturbations of different origins and identify fingerprints of these responses, by using a comprehensive atmosphere-ocean global circulation model coupled with a land surface model. Moreover, we quantify the changes in the carbon cycle during a collapse of the AMOC under pre-industrial conditions, considering both northern and southern possible origins. In this respect, both ocean response and the response of the land biosphere have been investigated with a special focus on a region of South America, where the model simulates particularly strong responses.

The reasons behind these abrupt changes found in the paleoclimate records have been surmised already in 1984 as a result of the nonlinear nature of the ocean-climate system (Oeschger et al., 1984). One such nonlinearity in the system is the existence of different modes of the thermo-haline circulation. At least some of the past abrupt climate changes, including the Younger Dryas event which caused intense cooling around the northern Atlantic and had climatic impacts over the globe, are considered to be a result of such rapid reorganizations (Boyle and Keigwin, 1987; Duplessy et al., 1988; Broecker, 1997; Clark et al., 2002). It is also documented in the records of ${ }^{14} \mathrm{C}$ and ${ }^{10} \mathrm{Be}$ that the ocean's ventilation in the North Atlantic was slowed during these cold periods (Hughen et al., 2000; Muscheler et al., 2000).

Any interruption in this ocean-wide circulation would have climatic effects both on regional and global scales. Those effects include intense cooling in the Northern Hemisphere, centred around Northern Europe and Greenland spreading to the northern Pacific (Okumura et al., 2009); changes in the marine ecosystem in the Atlantic (Schmittner, 2005) and sea level in the North Atlantic (Levermann et al., 2005); changes in precipitation patterns over the tropics due to the shift of the Inter-tropical Convergence Zone (ITCZ) (Vellinga and Wood, 2002; Dahl et al., 2005) and changes in the El Niño-Southern Oscillation phenomenon (Timmermann et al., 2005, 2007). The tropics have an important role in the abrupt climate change events, that is globalizing the Northern Hemispheric phenomenon of the AMOC shutdown through reorganizations in the ocean and the atmosphere (Chiang, 2009).

Understanding the response of the global carbon cycle to a large freshwater input into the ocean is necessary in order to explain the changes in the $\mathrm{CO}_{2}$ concentration in the atmosphere during those abrupt events. During the intense cooling events in Greenland and the more gradual Antarctic warm events, atmospheric $\mathrm{CO}_{2}$ records show small but significant variations. Antarctic warm events A1 to A4 had seen atmospheric concentrations of $\mathrm{CO}_{2}$ rise by about 20 ppmv (Stauffer et al., 1998; Indermühle et al., 2000), and by about the same amount during the much shorter Younger Dryas cold event (Monnin et al., 2001).

There are two different ideas regarding the source of this increase, that is either the ocean or the change of vegetation cover on land. While some modelling experiments have suggested that this atmospheric $\mathrm{CO}_{2}$ increase was due to an oceanic release of carbon (Marchal et al., 1999; Schmittner and Galbraith, 2008), others suggest that it was due to a land carbon release (Köhler et al., 2005; Obata, 2007; Menviel et al., 2008). Ocean outgassing, for instance, can explain the increasing atmospheric $\mathrm{CO}_{2}$ levels if the cooling of the sea surface is constrained to the high northern latitudes, the warming in the Southern Ocean is more pronounced and the contribution from land is not taken into account (Marchal et al., 1999). Schmittner and Galbraith (2008) also identified the ocean as the source of the atmospheric $\mathrm{CO}_{2}$ increase during abrupt climate change events. Due to the absence of a complex atmospheric component, however, their model is probably limited in representing tropical precipitation changes that have a potentially large impact on the land biosphere.

The other possible contributor to the carbon cycle changes during abrupt climate change events is the land biosphere. Köhler et al. (2005) have found that under both pre-industrial and pre-Younger Dryas conditions, atmospheric $\mathrm{CO}_{2}$ concentration rises due to the release of carbon from land, with the rise in the latter being slightly less pronounced.

More recently, Obata (2007) employed a general circulation model coupled with a simple land surface model to simulate an AMOC shutdown which caused a release of carbon from land resulting in an atmospheric $\mathrm{CO}_{2}$ increase. In another study, using an earth system model of intermediate complexity (LOVECLIM), Menviel et al. (2008) suggested that in the event of an AMOC shutdown, the ocean acted as a carbon sink and the land as a carbon source under both pre-industrial and LGM (Last Glacial Maximum) conditions. Our results support their conclusions in many ways and extend it further by offering a clearer picture of the reaction of the land biosphere. An alternative location for applying freshwater perturbations is also a feature of our study which gives insight as to which hemisphere might have triggered such events in the past. The fingerprints of each trigger (northern or southern) are evident in the South American continent, which is the centre of action for carbon cycle changes on land. A comparison of our model results with paleo-records in that region is also provided.

The paper is organised as follows; in Sect. 2 a brief description of the model and the experiments is given, in Sect. 3 the results of our experiments are explained, which is followed by the discussion and conclusions in Sect. 4 . 


\section{Methods}

\subsection{Model description}

The model used in this study is a modified version of the CSM1.4-carbon climate model developed by the National Centre for Atmospheric Research (NCAR) in Boulder, USA. It is a fully coupled 3-D climate model that consists of land, ocean, atmosphere and sea ice components integrated via a flux coupler without flux adjustments (Boville and Gent, 1999).

The CSM 1.4-carbon source code is available electronically on the CCSM website (http://www.ccsm.ucar.edu/ working_groups/Biogeo/csm1_bgc/). The detailed description of the model is given by Doney et al. (2006) and Fung et al. (2005). Further information on the sensitivity of the model to external forcing can be found in the literature (Fung et al., 2005; Frölicher et al., 2009; Frölicher and Joos, 2010; Steinacher et al., 2009, 2010).

The atmospheric component CCM3 of the model has a spectral truncation resolution of approximately $3.75^{\circ}$ (T31 Grid) and 18 vertical levels with 10 in the troposphere and 8 in the stratosphere (Kiehl et al., 1998).

The ocean component is called the NCAR CSM Ocean Model (NCOM) and has 25 vertical levels with longitudinal resolution of $3.6^{\circ}$ and latitudinal resolution between $0.8^{\circ}$ to $1.8^{\circ}$ (T31x3 Grid) (Gent et al., 1998). Since the original version of CSM1.0, modifications have been made on horizontal and vertical diffusivity and viscosity to improve the equatorial ocean circulation and inter-annual variability.

The sea-ice component has the same resolution as the ocean component and the land component has the resolution of the atmosphere component. The overall water cycle is closed through a river runoff scheme.

In the fully coupled carbon-climate model, atmospheric $\mathrm{CO}_{2}$ is a prognostic variable whose balance is determined by exchange fluxes with the land and ocean (Fung et al., 2005). The carbon-cycle in the ocean is based on the OCMIP-2 biotic carbon model (Najjar et al., 1992). The main differences between the original OCMIP-2 model and this model are that the biological source-sink term has been changed from a restoring formulation to a prognostic formulation and iron has been added as a limiting nutrient together with a parametrization for the iron-cycle (Doney et al., 2006).

The land biogeochemistry in the CSM1.4-carbon model is a combination of the NCAR Land Surface Model (LSM) (Bonan, 1996) and the Carnegie-Ames-Stanford Approach (CASA) biogeochemical model (Randerson et al., 1997), both of which are very well documented in the literature. Carbon is recycled in the CASA model following the life cycles of plant functional types (PFTs) through carbon assimilation via photosynthesis and carbon release via mortality, decomposition and microbial respiration (Fung et al., 2005). There are 3 soil texture types and 14 PFTs with fractional coverage of up to four PFTs within each model grid-box. Carbon assimilation is calculated by the LSM by estimating stomatal conductance of $\mathrm{CO}_{2}$ and water vapour in the leaves that are in shaded or directly lit conditions (Sellers et al., 1996). The net primary productivity (NPP) is fixed as $50 \%$ of the gross primary productivity (GPP) and is calculated by LSM to be allocated to three alive biomass pools of leaf, wood and roots. The allocation of NPP to these biomass pools is climate dependent, i.e., more of the NPP is allocated to the roots under water-limited conditions, while under light-limited conditions leaves are the preferred choice of biomass pool (Friedlingstein et al., 1999). In addition to three alive biomass pools, there are 9 dead biomass pools with leaf mortality contributing to the surface litter pool, root mortality contributing to the soil litter pool and wood mortality contributing to the coarse woody debris pool. The rest of the 9 dead biomass classes includes dead surface and soil microbial pools and slow and passive pools. The rate of transfer between different carbon pools is climate sensitive, determined by soil temperature and soil moisture saturation.

The carbon cycle is fully coupled to the water and energy cycles such that changes in the temperature and soil moisture calculated by LSM affect the NPP, allocation and decomposition rates and changes in the leaf area fraction calculated by CASA affect GPP transpiration and albedo. A terrestrial $\mathrm{CO}_{2}$ fertilization effect is inherent to the model because carbon assimilation via the Rubisco enzyme is limited by the internal leaf $\mathrm{CO}_{2}$ concentration that is dependent on the atmospheric $\mathrm{CO}_{2}$ concentration. Thus, the productivity increases with the atmospheric $\mathrm{CO}_{2}$ concentration, eventually saturating at high $\mathrm{CO}_{2}$ levels (Doney et al., 2006).

Other land surface processes that can affect atmospherebiosphere interactions, but are not implemented in this study include: explicit nitrogen cycle, fires, volcanic eruptions, dynamic vegetation change and anthropogenic land cover change.

\subsection{Experimental setup}

The model used in this study was brought to steady state with the 1000-year spin-up procedure undertaken by Doney et al. (2006). The 1000-yr integration is nearly stable with a minimal drift in the deep ocean. There are known biases in this spin-up, which include a cold bias in the surface air temperature (SAT) over the continental interior in the Northern Hemisphere, precipitation anomalies in the tropics such as the formation of the ITCZ over the Pacific as two bands of excess precipitation, and too much or too little precipitation over land in some tropical regions of South America, Central Africa and Southeastern Asia. These biases in the physical climate also lead to corresponding anomalies of NPP and carbon storage on land that include an underestimation of NPP in higher latitudes and an overestimation in lower latitudes. Nevertheless, overall global NPP compares well with the reconstructed pre-industrial levels of NPP. The simulated climatologies in carbon inventory and fluxes resemble those 
determined from available observations. Atmospheric $\mathrm{CO}_{2}$ excursions are small, $4 \mathrm{ppm}$ over several centuries, and no abrupt changes are found during the integration. The spin-up stops at the $1820 \mathrm{AD}$ atmospheric $\mathrm{CO}_{2}$ levels and our experiments start at this point in time. Additional runs with two of the freshwater settings have been performed starting from a slightly different point in time at the steady state in order to account for the effects of short term variability in the climate system. The starting points for those additional runs are chosen with a different ENSO state than the original runs.

The freshwater hosing experiments (Table 1) are designed to investigate the response of the ocean and climate system to a freshening of the surface water around the key deep water formation sites in the Northern and Southern Hemispheres under pre-industrial conditions of atmospheric $\mathrm{CO}_{2}$ (278 ppm). Perturbations applied simulate a change in the freshwater budget of the high-latitude ocean as a result of a surge in glacial melt-water from Greenland, Antarctica, or other pre-industrial continental glacial formations such as the Laurentide icesheet, which is responsible for the abrupt climate events of Younger Dryas 12.7-11.6 cal kyr BP and another smaller one during Holocene around 8200 yr BP (Barber et al., 1999).

It is important to note here that even though we compare our results with paleoclimate reconstructions, the boundary conditions used in our experiments are not glacial boundary conditions which had significantly different levels of atmospheric $\mathrm{CO}_{2}$, as well as differences in temperature, precipitation and biome distribution, especially in mid- and highlatitudes. In the Discussion section, we address this issue by comparing it to a previous study by Menviel et al. (2008).

For each perturbation the freshwater input was assumed to be a rectangular pulse uniform over 100 years. The duration of each run is 300 years including the duration of the perturbations. The three different sites where the freshwater is applied are the northern Atlantic Ocean between the latitudes of $50^{\circ} \mathrm{N}$ and $70^{\circ} \mathrm{N}$ (including the Labrador Sea) and the Weddell Sea and Ross Sea in the Southern Ocean.

The perturbation, which is actually a negative salinity flux as there is no actual water volume in the parametrization of the model, is set to correspond to a freshwater flux of $1.0 \mathrm{~Sv}$ (in two of the experiments smaller perturbations of $0.5 \mathrm{~Sv}$ and $0.3 \mathrm{~Sv}$ are applied) distributed uniformly across the area of the perturbation. There has been no salt compensation performed (Stocker et al., 2007). The amounts of the freshwater fluxes are highly idealized and do not directly correspond to the recorded events in the past.

\section{Results}

\subsection{Global average}

The most direct response of the climate system to a freshwater perturbation is a reduction in the maximum strength
Table 1. List of experiments given together with the region where freshwater is applied and the size of the perturbation. Different starting years for perturbations in the ensemble experiments refer to the date in the Control and are chosen according to the ENSO index in order to account for the effect of natural variability in the system. In addition to the ensemble experiments, three sensitivity simulations have been performed to investigate the effect of a different perturbation size and/or freshwater input region.

\begin{tabular}{|c|c|c|c|}
\hline Experiment & Freshwater Input & Freshwater Flux (Sv) & Start Year \\
\hline Control & - & - & 0 \\
\hline \multicolumn{4}{|c|}{ Ensemble Experiments } \\
\hline $1.0 \mathrm{NA}-1$ & North Atlantic & 1.0 & 0 \\
\hline 1.0 NA-2 & $"$ & 1.0 & 30 \\
\hline $1.0 \mathrm{NA}-3$ & $"$ & 1.0 & 126 \\
\hline $1.0 \mathrm{NA}-4$ & $"$ & 1.0 & 263 \\
\hline $1.0 \mathrm{NA}-5$ & " & 1.0 & 295 \\
\hline 1.0 Ros-1 & Ross Sea & 1.0 & 0 \\
\hline 1.0 Ros- 2 & $"$ & 1.0 & 30 \\
\hline 1.0 Ros-3 & $"$ & 1.0 & 126 \\
\hline 1.0 Ros-4 & $"$ & 1.0 & 263 \\
\hline 1.0 Ros-5 & $"$ & 1.0 & 295 \\
\hline \multicolumn{4}{|c|}{ Sensitivity Experiments } \\
\hline $1.0 \mathrm{Wed}$ & Weddell Sea & 1.0 & 0 \\
\hline $0.3 \mathrm{NA}$ & North Atlantic & 0.3 & 0 \\
\hline $0.5 \mathrm{NA}$ & $"$ & 0.5 & 0 \\
\hline
\end{tabular}

of the North Atlantic Meridional Overturning Circulation (Fig. 1a). By the end of the perturbation, the maximum North Atlantic MOC strength is reduced from around $24 \mathrm{~Sv}$ to $2 \mathrm{~Sv}$ for experiment $1.0 \mathrm{NA}$ and to $4 \mathrm{~Sv}$ and $6 \mathrm{~Sv}$ for experiments $0.5 \mathrm{NA}$ and 0.3 NA, respectively. Along with this reduction in the North Atlantic Deep Water, the Antarctic Bottom Water penetrates further into the Atlantic. For the 1.0 NA experiment, the circulation does not recover during our simulations, whereas in the $0.5 \mathrm{NA}$ and $0.3 \mathrm{NA}$ experiments it regains its original strength by the end of the experiments.

In response to a freshwater flux from near Antarctica (1.0 Wed and 1.0 Ros), the strength of the North Atlantic MOC slightly increases in the beginning, which is followed by a reduction of smaller magnitude than in the $1.0 \mathrm{NA}$ experiment. The mechanism behind this is explained by Stouffer et al. (2007) as the dilution effect, i.e., freshwater input from the Southern Ocean, does not stay there but is rather transported to the other parts of the ocean. This is evidenced by the time evolution of salinity. The result of the freshwater perturbation is a decrease in the global mean surface air temperature (SAT) in all experiments (Fig. 1b). Together with the changes in the precipitation fields, these two climatic variables cause the atmospheric $\mathrm{CO}_{2}$ concentration to increase by up to $20 \mathrm{ppmv}$ in the $1.0 \mathrm{NA}$ experiments and to decrease by up to $10 \mathrm{ppmv}$ in the Southern Ocean experiments (Fig. 1c). 


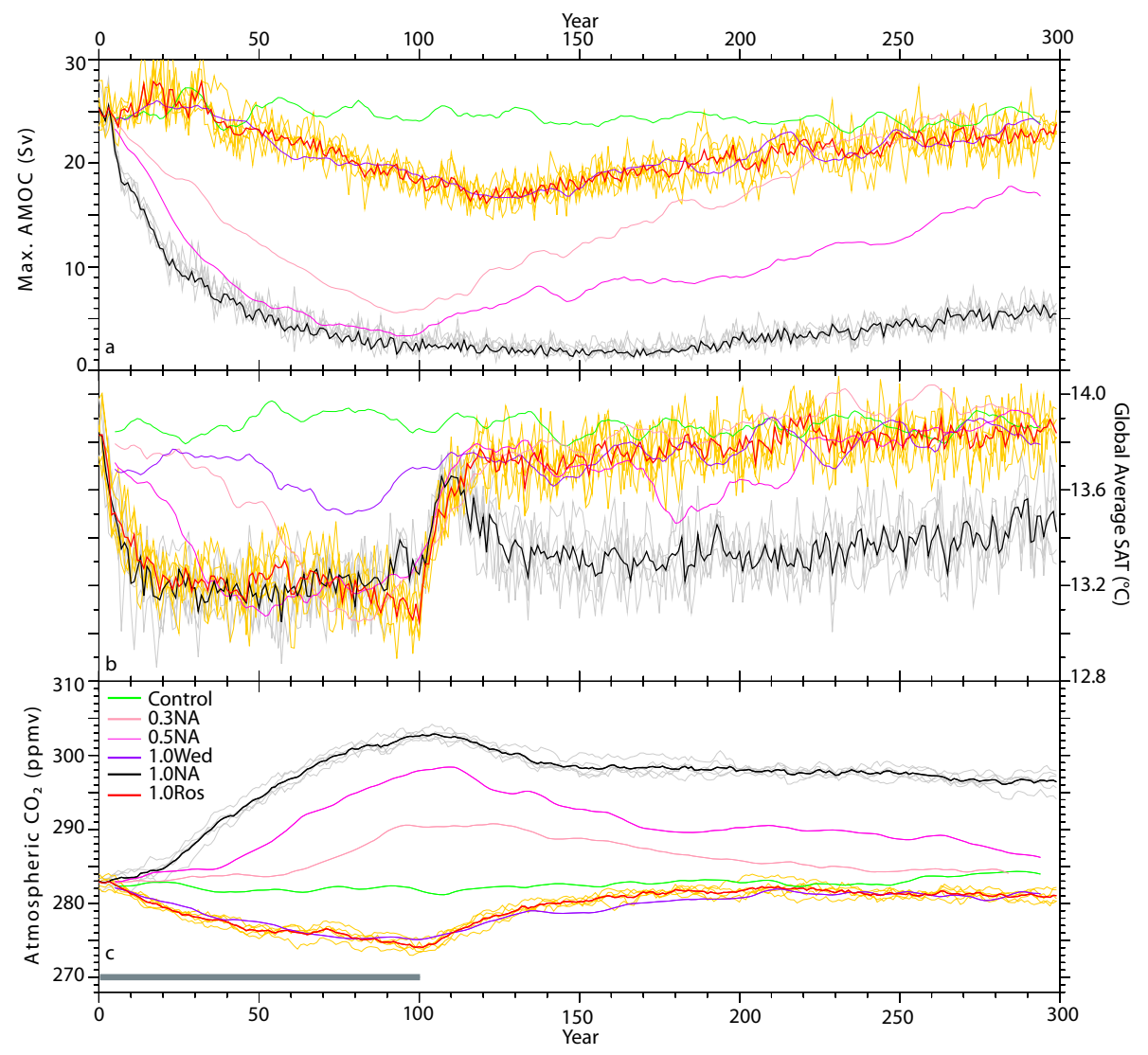

Fig. 1. Time series of: (a) Maximum North Atlantic MOC strength (Sv), (b) Global Annual Mean SAT $\left({ }^{\circ} \mathrm{C}\right)$ and (c) surface atmospheric $\mathrm{CO}_{2}$ concentration (ppmv). The green curve represents the Control; pink and magenta represent the smaller perturbations from the NA of 0.3 and $0.5 \mathrm{~Sv}$, respectively, and violet represent the 1.0 Wed perturbation. The other two perturbations of $1.0 \mathrm{NA}$ (black) and 1.0 Ros (red) are given as the averages of five ensemble members and the grey and orange curves in the background are the five individual runs in each ensemble, intended to show the spread of the anomalies. The values are 10-year box averages. The grey bar at the bottom marks the duration of the freshwater input.

\subsection{Physical response}

Because temperature and precipitation changes impact the carbon cycle, we first present changes in these two variables.

In the 1.0 NA experiment annual mean surface air temperature in the Northern Atlantic region decreases drastically (Fig. 2, left column) with reduced heat input from lower latitudes, as a result of the shutdown of the MOC in the Atlantic. Anomalies of up to $-15^{\circ} \mathrm{C}$ are observed over the North Atlantic between Iceland and Scandinavia. The cooling is not confined to the North Atlantic region but further extends to the high latitudes over North America and Asia. In line with the idea of inter-hemispheric redistribution of heat, the Southern Hemisphere exhibits warm anomalies of up to $3{ }^{\circ} \mathrm{C}$ over the Southern Pacific, Atlantic and Indian oceans and up to $6{ }^{\circ} \mathrm{C}$ over South America. In 1.0 NA, this general pattern stays roughly the same even 200 years after the end of the freshwater input, except for a temporary spike in the SAT coinciding with the end of the perturbation. The reason for that warming lies in the subsurface warming in the North Atlantic as a result of the increased stratification. A resumption of the vertical mixing, once the freshwater perturbation is switched off, brings up water to the surface from the subsurface warm pool which was created during the AMOC shut-down. By that time, this subsurface warm pool is mixed with the surface water and, subsequently, the atmosphere. However, this mixing is insufficient to restart the AMOC because of the diluted state of the surface water. Even though there is a slight increase in the salinity during this exchange, it is not enough to bring it to the original values. To a lesser extent, the warming is also caused by the delayed warming in the Southern Hemisphere, as it takes time for the warming to penetrate towards Antarctica.

Generally, the duration and severity of the atmospheric cooling (and warming) is dependent on the size of the freshwater flux. However, South America remains the region where the strongest warming occurs in all the North Atlantic experiments.

In the 1.0 Ros and 1.0 Wed experiments the strongest cooling in surface temperatures is observed in the Southern 

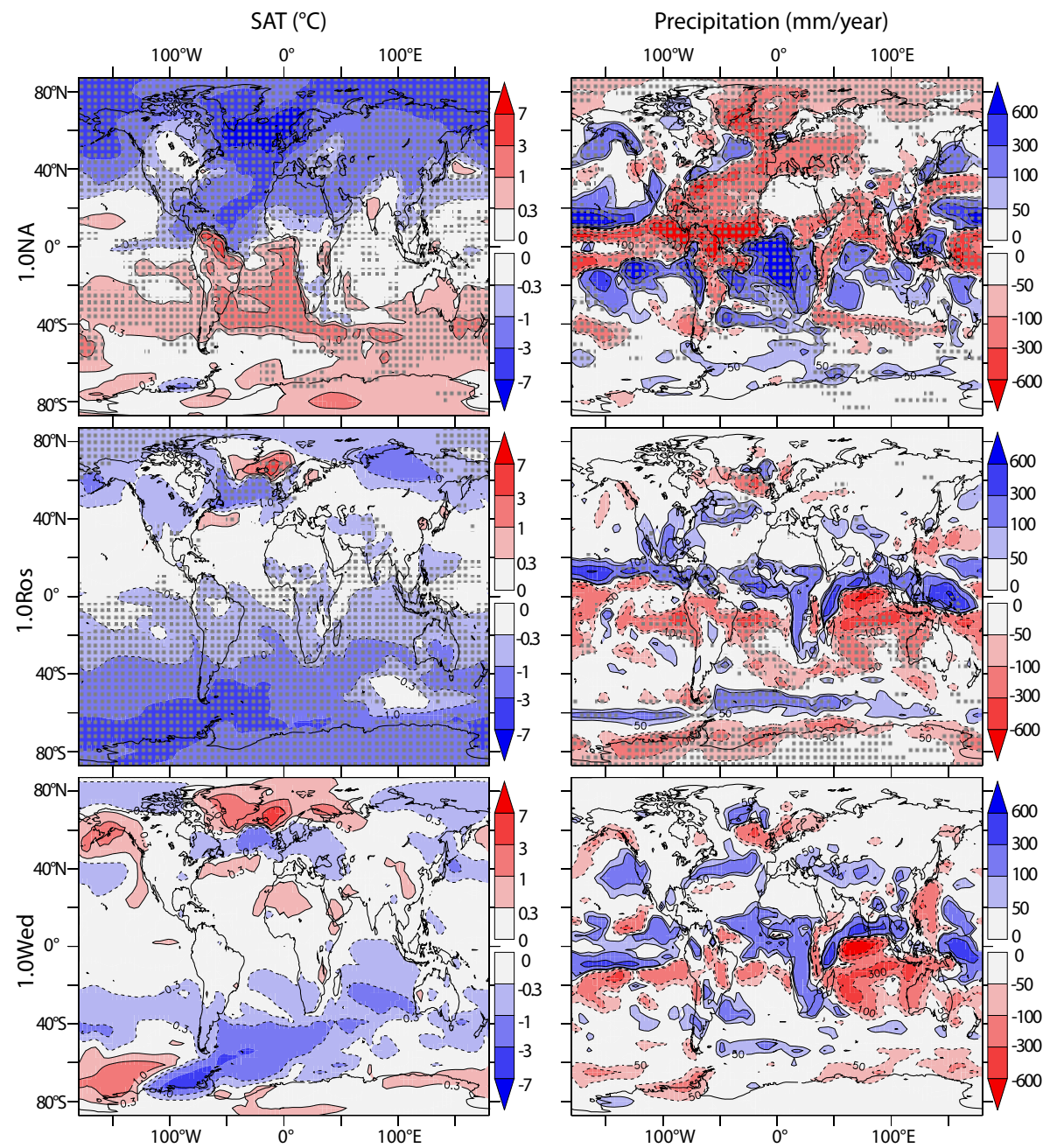

Fig. 2. The left column shows the SAT anomalies $\left({ }^{\circ} \mathrm{C}\right)$ with respect to the Control by the end of the 100 -year perturbation $($ decadal average of the model years 97-106) for the experiments 1.0 NA (top), 1.0 Ros (middle), and 1.0 Wed (bottom). The right column shows the precipitation anomalies $\left(\mathrm{mm} \mathrm{yr}^{-1}\right)$. Stippled areas indicate where the ensemble mean anomaly is significantly different from zero at the $67 \%$ level (Student's t-Test). Confidence level of the 1.0 Wed experiment results is not quantified since there is only one simulation available.

Hemisphere near Antarctica and the strongest warming is in the Northern Hemisphere near Greenland. But in the 1.0 Ros experiment, partial cold anomalies can also be seen in the Northern Hemisphere high latitudes. Because of this more widespread cooling in the 1.0 Ros experiment, the range of global average SAT anomaly is comparable to the 1.0 NA experiment, even though local anomalies are not as severe.

Overall, the regional amplitudes of the anomalies are smaller for the Southern Ocean perturbations. This is in line with the fact that there is a smaller reduction in the AMOC strength, as mentioned in the previous section. This can be due to the fact that freshwater is diluted in the larger volume of the Southern Ocean. Thus, a larger freshwater input is needed in order to achieve a response similar in magnitude to the 1.0 NA experiment.
As air temperature and sea surface temperature play a great role in the determination of the precipitation patterns, a change in those fields also cause a change in the amount and distribution of precipitation over the globe (Fig. 2, right column). The largest precipitation anomalies occur mainly at low latitudes and over the oceans, where water vapour availability is the greatest. But for the following analysis of the land biosphere, the most important changes are in South America and Africa. In the 1.0 NA experiment, total annual precipitation anomalies of up to $1.6 \mathrm{~m}$ are recorded in those locations.

The distribution of the most severe precipitation anomalies near the equator is consistent with what is expected from a shift of the ITCZ. Northern Atlantic perturbations cause a southward shift of the ITCZ as a result of the cooling in the Northern Hemisphere, whereas perturbations from the Southern Ocean cause a northward shift. This northward 


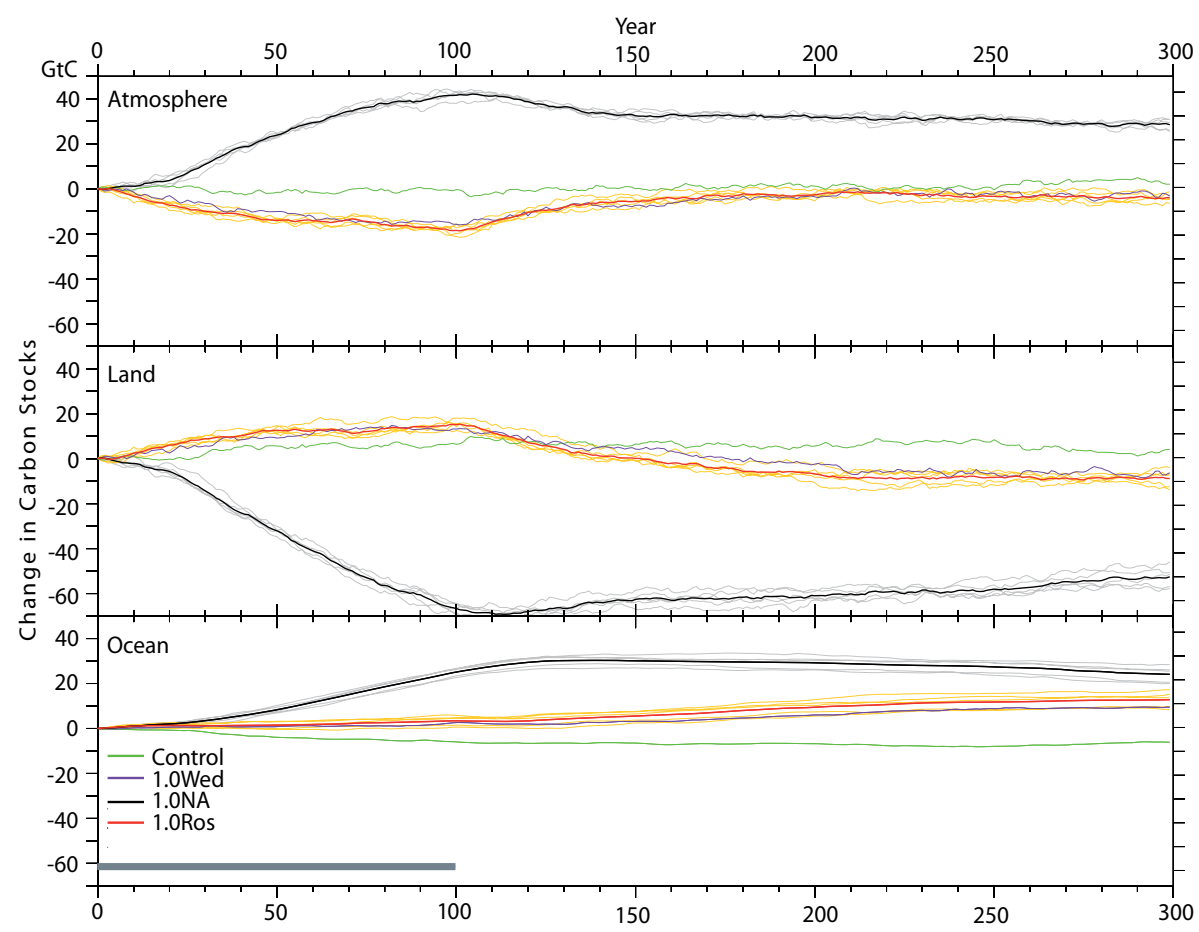

Fig. 3. Responses to freshwater perturbations of different carbon inventories: atmosphere (top), land (middle), and ocean (bottom). The values are the anomalies with respect to the 100-year average of the Control and given in GtC. Values are 10-year box averages. The two perturbations of 1.0 NA (black) and 1.0 Ros (red) are given as the averages of five ensemble members and the grey and orange curves in the background are the five individual runs in each ensemble. The grey bar at the bottom marks the duration of the freshwater input.

migration of the ITCZ was also simulated in a study by Menviel et al. (2010). In that study, freshwater was applied uniformly over the Southern Ocean leading to similar changes in the ocean circulation and deep water formation. A decrease in the SST and SAT values in the Southern Hemisphere accompanied by subsurface warming in the Southern Ocean is also one of the commonalities.

\subsection{Response of the carbon cycle}

\subsubsection{Changes in the global carbon inventories}

Climatic change, as a result of a freshwater perturbation as in our experiments, affects the distribution of carbon in the three main reservoirs of land, ocean and atmosphere. The freshwater perturbations from the northern deep water formation site cause an increase in the atmospheric carbon inventory, while the southern perturbations cause a decrease and associated changes in each carbon inventory (Fig. 3).

The response of the land carbon stocks to the three perturbations from the North Atlantic amounts to a decrease by several tens of GtC. The magnitude of this decrease is proportional to the strength of the freshwater perturbation. It is also important to note here that in the control run a drift of about $-6 \mathrm{GtC}$ over 300 years is recorded in the ocean. This does not invalidate our experiments as the magnitude is relatively small. The negative carbon drift in the ocean is slightly masking the carbon uptake by the ocean in all experiments.

Changes in the land carbon stocks immediately affect the atmosphere, while the time required for this perturbation to reach the much larger inventory of the ocean is longer. The land carbon stocks decline as a response to the 1.0 NA perturbation causing the atmospheric $\mathrm{CO}_{2}$ to increase, which, in time, is partially taken up by the ocean. Yet, in the time frame of our simulations a larger than expected portion of the carbon emitted from land remains in the atmosphere. This indicates that the ocean does not behave like a passive carbon sink, in which case it would be expected to take up a much larger proportion of the carbon emitted to the atmosphere. Instead, after the initial increase, total carbon in the ocean stays quite stable until the end of the experiment. This points to a reorganization of the ocean carbon cycle, which leads to a new equilibrium with the atmosphere.

For the 1.0 NA experiment, emissions from the land biosphere exceed $60 \mathrm{GtC}$ by the end of the perturbation, and yet only about $20 \mathrm{GtC}$ are taken up by the ocean by the end of the experiment. This amount corresponds to less than one third of the total emitted carbon by the land biosphere. At this time, some $30 \mathrm{GtC}$ are still in the atmosphere and about $15 \mathrm{GtC}$ go back to the land due to the recovery of the land biosphere. The changes in carbon stocks scale with the size of the freshwater perturbations. 

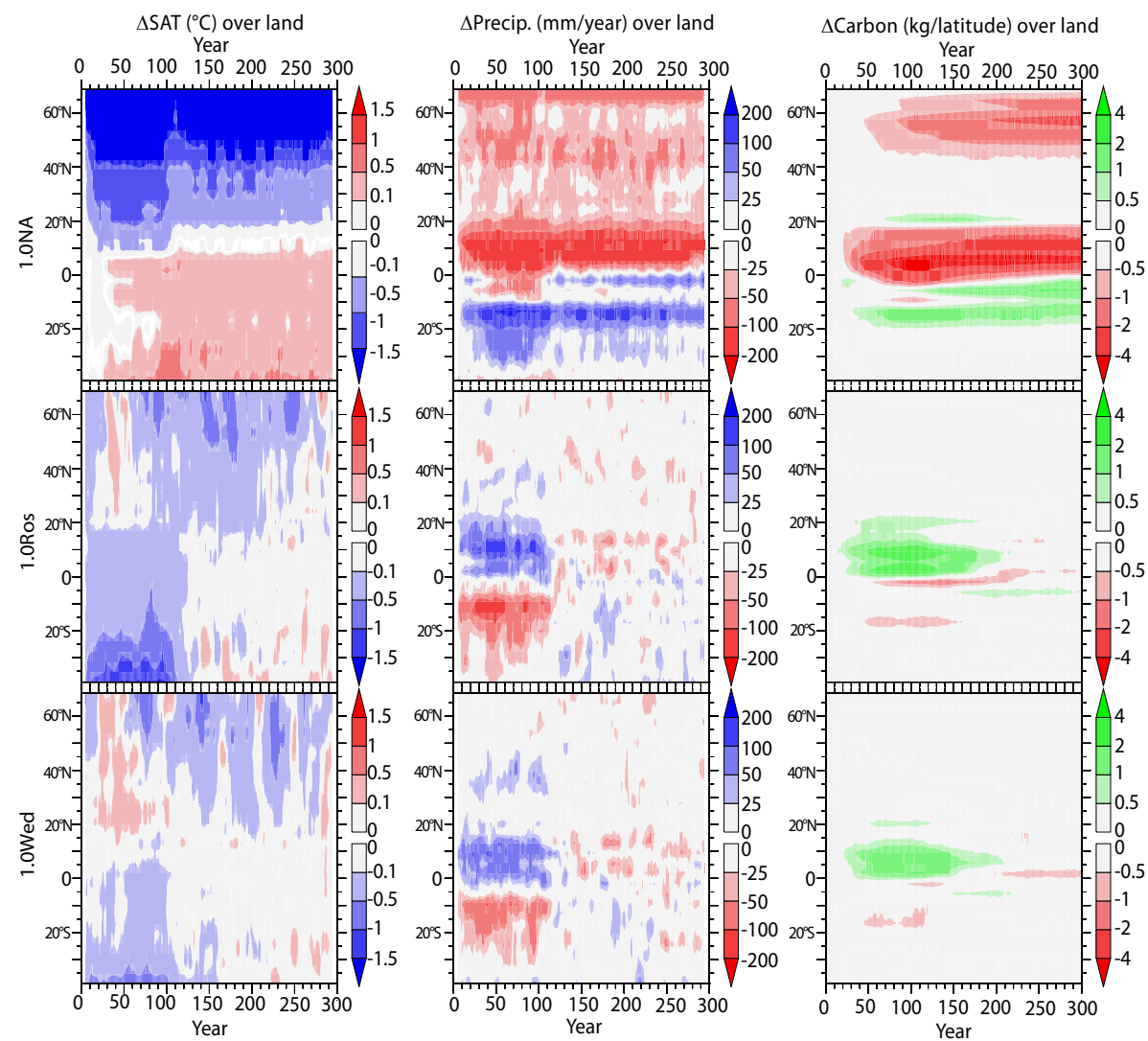

Fig. 4. From top to bottom, each row represents the experiments 1.0 NA, 1.0 Ros, and 1.0 Wed, respectively. Given in each column are zonal mean changes of temperature (left), precipitation (middle) and total carbon per latitude (right) on land. The precipitation and the SAT values are averaged over 10 years.

In the experiments with a freshwater input from Antarctica, the change in the land carbon stocks is an increase. The peak values of the increase in the land carbon pools are about $20 \mathrm{GtC}$ for experiment 1.0 Ros and about $12 \mathrm{GtC}$ for $1.0 \mathrm{Wed}$, resulting in a reduced atmospheric $\mathrm{CO}_{2}$ concentration. However, these changes are not permanent and return to their original values soon after the perturbations stop. Changes in the ocean carbon inventory are smaller, reaching about $10 \mathrm{GtC}$ by the end of the experiments and cannot be easily distinguished from the variations in the control. It is safe to assume that a southern perturbation on a scale comparable to our experiments (that is to say less intense than a northern perturbation) creates changes in the land biosphere that are relatively short-lived. The response of the ocean to decreasing atmospheric $\mathrm{CO}_{2}$ concentrations would be releasing carbon to balance it. Whereas, the slight increase in the oceanic carbon instead of an expected decrease leads us to believe that the changes in the carbon cycle in the ocean play a role in this experiment, too. Hence, the stable behaviour of the ocean carbon inventory during the first 140 years of the 1.0 Ros experiment is probably due to the fact that the competing effects of the reorganization of the carbon cycle and the decrease of the atmospheric $\mathrm{CO}_{2}$ concentrations due to land uptake cancel each other out.
A similar experiment performed with the LOVECLIM climate model did not lead to any significant changes in atmospheric $\mathrm{CO}_{2}$ (Menviel et al., 2010).

\subsubsection{A more regional look}

The response of the land biosphere shows clear latitudinal dependencies accompanied by the strong latitudinal coupling of the climate parameters, temperature and precipitation. Figure 4 shows the zonal averages of the changes in the temperature and precipitation fields over land, and total land carbon stocks per latitude. Changes in the carbon stocks closely follow the changes in the precipitation in lower latitudes, while in higher latitudes temperature anomalies become more dominant. This is not surprising given the fact that, as a result of an MOC shutdown, in the higher latitudes temperature anomalies are larger than precipitation anomalies and the lower latitudes experience substantial changes in precipitation due to the shift of the ITCZ and the exponential dependence of saturated water vapour pressure to temperature. Hence, small temperature changes translate into large differences in precipitation in the tropics where the ambient temperature is higher (Bard, 2002). Nevertheless, globally, precipitation anomalies are responsible for most of the change 


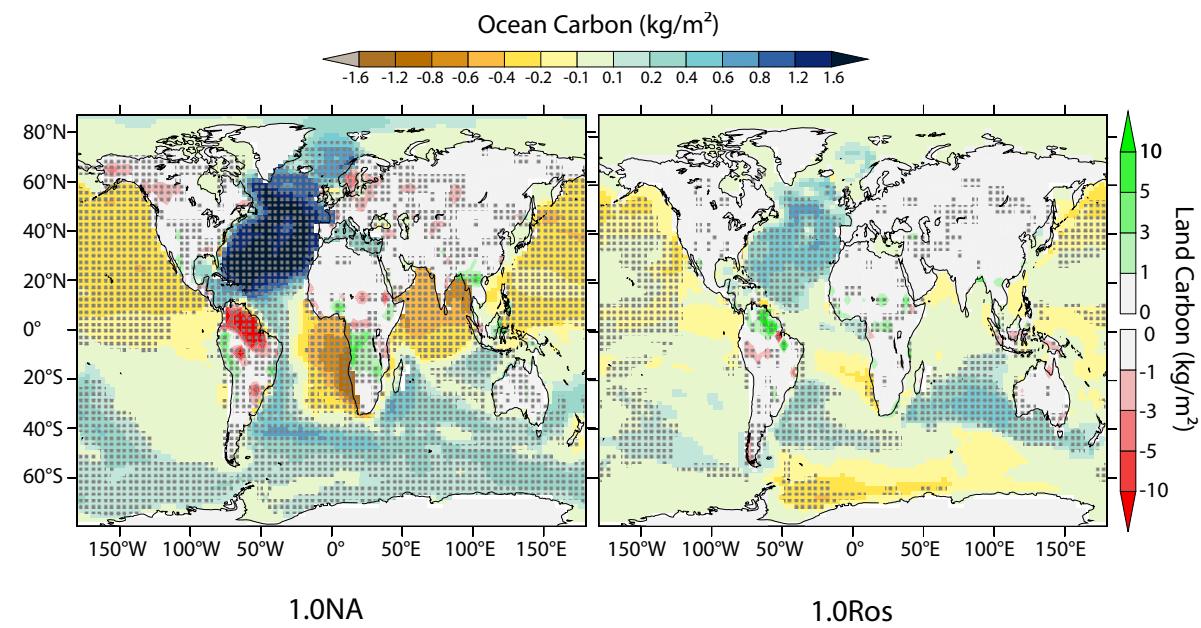

Fig. 5. Changes in the carbon stocks $\left(\mathrm{kg} \mathrm{m}^{-2}\right)$ in the ocean and on land (note the different colour bars) for $1.0 \mathrm{NA}$ and 1.0 Ros experiments, by the end of the perturbation (decadal average of model years 97-106). Stippled areas indicate where the ensemble mean anomaly is significantly different from zero at the $67 \%$ level (Student's t-Test).

in the carbon stocks on land as most of the carbon emissions stem from the large vegetation pool of the low latitudes.

However, Fig. 4 cannot capture the inhomogeneous distribution of changes within those climatic zones. Therefore, we consider a snapshot of the distribution of the changes in the carbon stocks both on land and in the ocean (Fig. 5). In the ocean, most of the carbon ends up in the Atlantic Ocean. However, this does not necessarily mean an increased air-sea gas exchange in this region. The main reason for the carbon build-up in the Atlantic is the increased transport of DIC-rich Antarctic Bottom Water and a smaller amount comes from the air-sea gas exchange. The decreased primary production makes a small negative contribution. This reorganization also causes the reduction of total carbon in the other oceans, especially in the northern part of the Pacific and Indian Oceans. The contribution from the air-sea gas exchange is positive in the Pacific and Indian oceans, whereas in the Southern Ocean outgassing prevails. The carbon stocks in the North Pacific are influenced negatively by the increased circulation at depth due to the onset of deep water formation in this region. The initiation of North Pacific meridional overturning as a result of the AMOC shutdown has also been reported in previous modelling and reconstruction studies (Mikolajewicz et al., 1997; Okazaki et al., 2010; Menviel et al., 2011). This is an interesting feature which requires further investigation with regards to the underlying mechanisms. However, this is beyond the scope of the present study.

On land, the biggest changes occur in the tropical regions of South America, Africa and southeastern Asia, with the high latitudes contributing to anomalies smaller in magnitude but more widespread. As has been shown in Fig. 4, the regions near the equator exhibit large precipitation anomalies due to the shift of the ITCZ, either positive or negative.
In order to account for the life-cycle of the land vegetation and different cycling time-scales of carbon, the model includes various carbon pools, as mentioned in the methods section. The biggest change occurs in the vegetation pool (Fig. 6). Carbon inventories in the vegetation decrease in northern latitudes and in northern South America. The response of the soil carbon is determined by the competing influences of the input from the vegetation pool as well as the microbial overturning in the soil, which is reduced due to the lower temperatures. The sum of these two influences at high latitudes, where bigger proportions of carbon are stored in the soil, is a small increase in soil carbon. Where the temperature change is positive, as is the case in parts of South America, the proportion of the soil carbon compared to the carbon stored in the vegetation cover is small. In northern South America soil carbon content amounts to about $8 \mathrm{~kg} \mathrm{~m}^{-2}$ on average, whereas average carbon stored in the vegetation cover is more than $20 \mathrm{~kg} \mathrm{~m}^{-2}$. Because of these factors, the contribution of the soil carbon pool to the changes in the atmospheric $\mathrm{CO}_{2}$ concentration remains small.

In order to quantify the correlation between the anomalies in various climatic variables and the changes in the carbon stocks on land, a linear regression analysis has been performed. As the vegetation carbon pool is the biggest contributor to those changes and it is directly affected by the changes in the net primary production (NPP), which in turn is determined by the climate, NPP is chosen as the variable of interest for this comparison. Figure 7 shows the the sensitivity of the NPP to those variables, given here with the colour shading. This reveals the latitudinal dependency of the sensitivity of NPP, especially to temperature anomalies; there is a positive dependence in the colder climates of high latitudes, whereas it is negative in the warmer tropical regions. Also shown in the figure is the correlation between NPP and three 


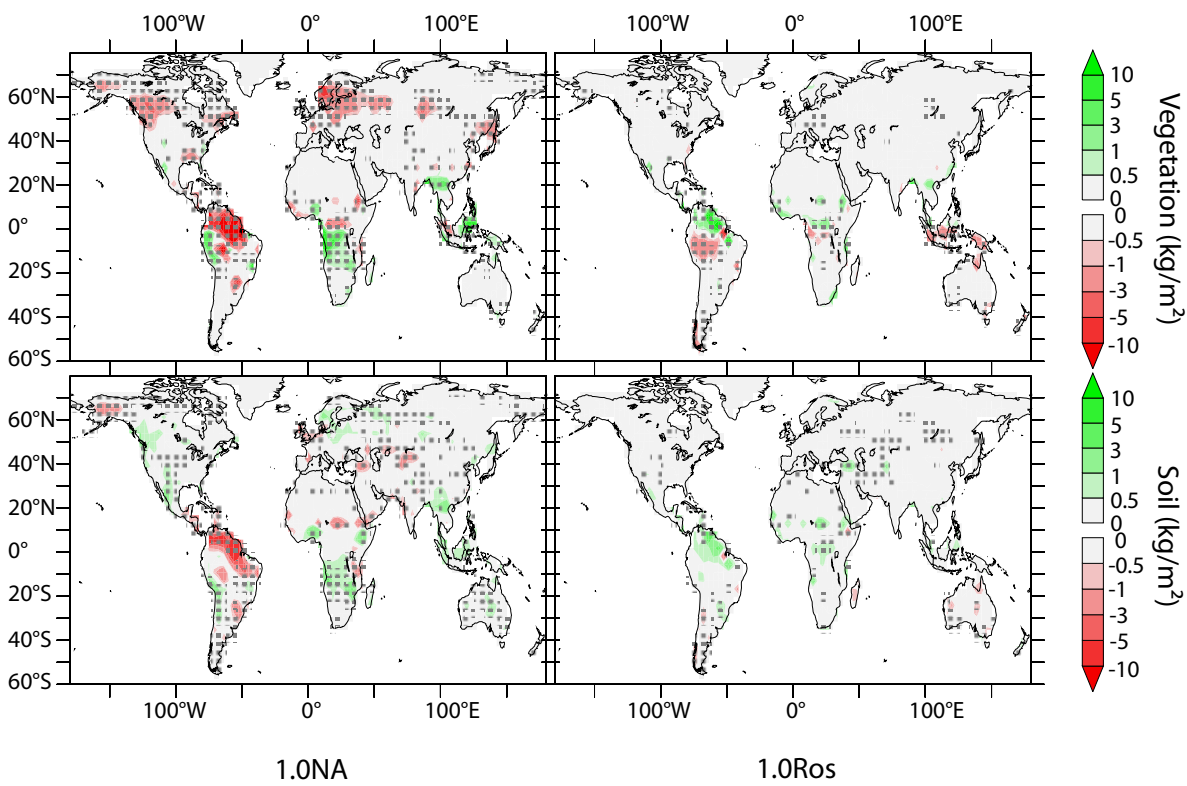

Fig. 6. Changes in the vegetation and soil (including litter) carbon $\left(\mathrm{kg} \mathrm{m}^{-2}\right)$ by the end of the perturbation (decadal average) for the experiments 1.0 NA (left) and 1.0 Ros (middle). Stippled areas indicate where the ensemble mean anomaly is significantly different from zero at the $67 \%$ level (Student's t-Test).

climatic variables, temperature, precipitation and soil moisture. Soil moisture shows the highest correlation with NPP, as it is a composite variable that is determined by both precipitation and temperature. Correlation is generally higher in low latitudes for precipitation and soil moisture, while temperature shows a better correlation in the high latitudes. Nevertheless, South America stands out as a region of high correlation for each of the variables mentioned, including temperature.

\subsubsection{South America - a more detailed analysis}

In our model simulations, the contribution of the South American continent to the global atmospheric $\mathrm{CO}_{2}$ rise (or fall, in the case of southern perturbations) is disproportionately high compared to the rest of the world. About half of all the losses in the land carbon pool is from the northern part of South America in the 1.0 NA experiment, as well as a comparable fraction of the gains in the 1.0 Ros experiment (Table 2).

The net change in the total carbon stocks in the northern part of South America (the region marked in Fig. 8 top left) is more than $40 \mathrm{GtC}$ by the end of the 100 -year perturbation. The driving factors of this substantial change are the increasing temperature and reduced precipitation, the combined effect of which is the transformation of one of the wettest climates on land into an arid desert-like climate unable to sustain the carbon-rich rain-forest type vegetation.

Precipitation decreases by about $400 \mathrm{~mm} \mathrm{yr}^{-1}$ and the surface air temperature rises by $1.4{ }^{\circ} \mathrm{C}$ on average (Fig. 9). Soil carbon also decreases significantly, but this amounts to only half of the change in the vegetation carbon pool.

The response in the northern South America is a combination of changes in the precipitation and the air temperature, which is influenced by the prevailing winds. Over the ocean, where water vapour availability is primarily governed by the sea surface temperature, a positive correlation between the SAT and precipitation is apparent in most places. Over land, on the other hand, wind-driven transport of moisture from the sea is crucial. The north-easterlies that carry moist air to northern South America are weakened (Fig. 10) and, due to the colder SST in the northern equatorial Atlantic, their moisture content is reduced, which makes the region drier. This, in turn, results in a substantial drop in the latent heat flux (Fig. 9 last panel), most of which is due to reduced canopy transpiration as a result of the decrease in rain-forest vegetation. Consequently, a larger portion of the heat is transferred as sensible heat, raising the SAT. Removal of the rain-forest type vegetation, therefore, creates a very important feedback which further reduces the evapotranspiration and the latent heat flux.

The dramatic change in the northern part of South America also persists in the 1.0 Ros experiment, though with an opposite sign. As in the 1.0 NA experiment, a greater portion of the total anomaly in this experiment is in the vegetation carbon pool and it follows the changes in the climate field; higher precipitation and lower SAT values that lead to higher soil moisture.

The rest of the continent is also affected significantly by the changes in the climate system. Among them are the 

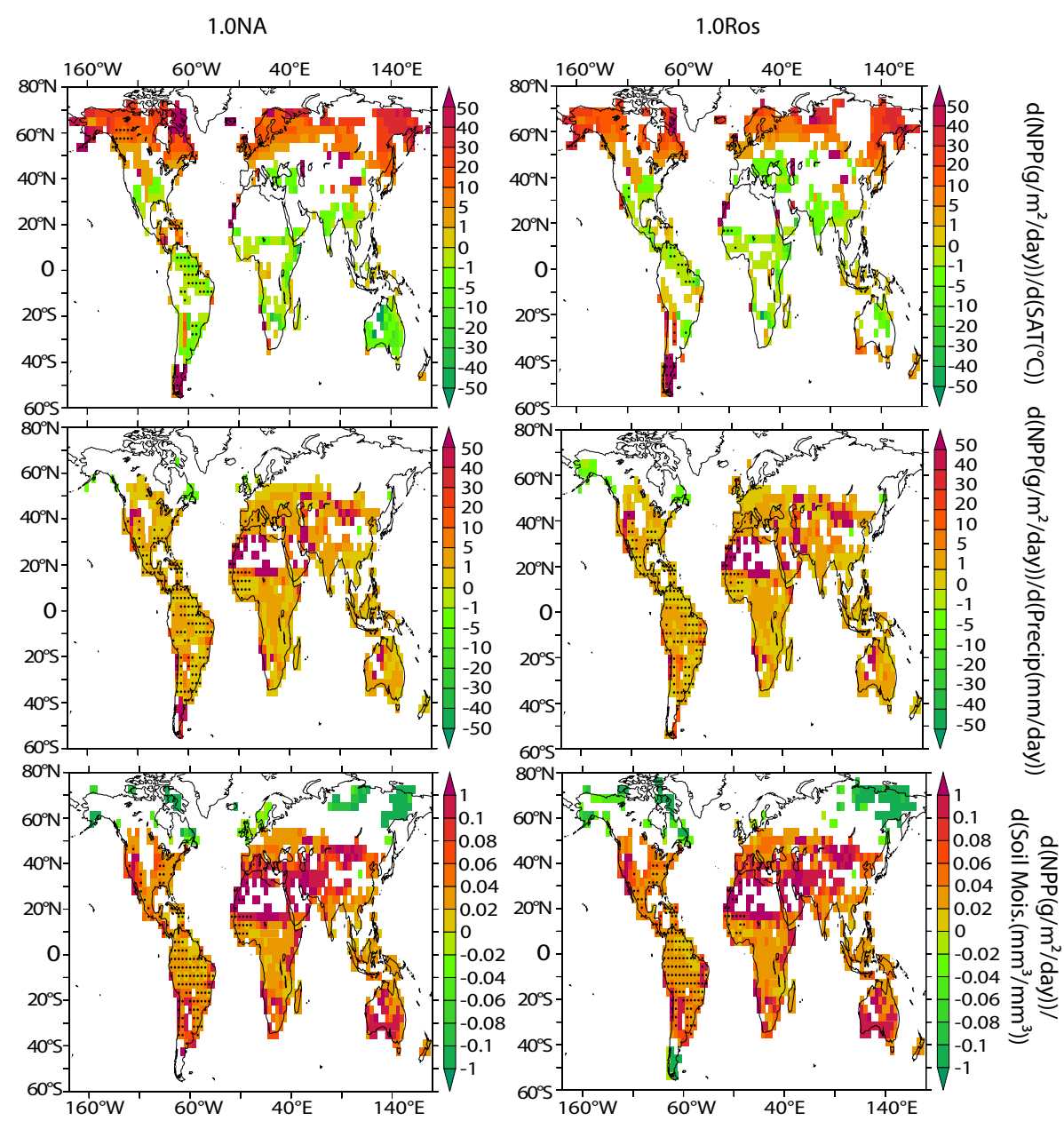

Fig. 7. Results of a linear regression analysis between NPP $\left(\mathrm{g} \mathrm{m}^{-2} \mathrm{day}^{-1}\right)$ and the climatic variables of SAT $\left({ }^{\circ} \mathrm{C}\right.$, top), precipitation $\left(\mathrm{mm}\right.$ day $^{-1}$, middle), and soil moisture $\left(\mathrm{mm}^{3} \mathrm{~mm}^{-3}\right.$, bottom). Colour shading represents the sensitivity of NPP to the changes of these variables (slope of the linear regression). Only the grid cells with a value of the square of the correlation coefficient greater than 0.1 $\left(R^{2}>0.1\right)$ are coloured and the cells with $R^{2}>0.5$ are both coloured and stippled. The 1.0 NA experiment is given on the left column and 1.0 Ros on the right.

western part of the continent and northeastern Brazil, both of which respond oppositely relative to the northern part of the continent such that, NPP increases in the 1.0 NA experiment and decreases in the 1.0 Ros experiment. Those changes, basically, follow the shift of the ITCZ. The opposite impact (relative to the northern South America) of the ITCZ displacement on the climate and vegetation of the northeastern Brazil during the Younger Dryas (Wang et al., 2004) and Heinrich events (Dupont et al., 2010) is also evident in the records of the past climate.

The high-latitude regions of South America do not play an important role, in general. Although the southern parts of South America show a decrease in the carbon stocks in 1.0 Ros experiment due to the lower temperatures, compared to the other regions, it does not add up to significant values. This is simply because of the initially small size of the carbon pool in that region.
Figures 8 and 9 reveal the characteristic property of a South American response to a reduction in the thermohaline circulation, which is a distinct and opposite reaction at the two different locations of the freshwater perturbation. 1.0 NA and 1.0 Ros experiments produce opposite responses not only in the north of the continent, but also in the rest of the continent (central/northeastern Brazil and possibly the western part of the continent) that form a dipole relationship with the north. Currently, the ITCZ over South America is located northward of the continent, and northeastern Brazil has a semi-arid climate. During reduced AMOC, the north end of this continental dipole responds in a positive way to a North Atlantic perturbation while the other end responds negatively, and vice-versa in the case of a southern perturbation. This kind of a decoupling of the precipitation response within the continent is also documented in other studies (Cruz et al., 2009). 


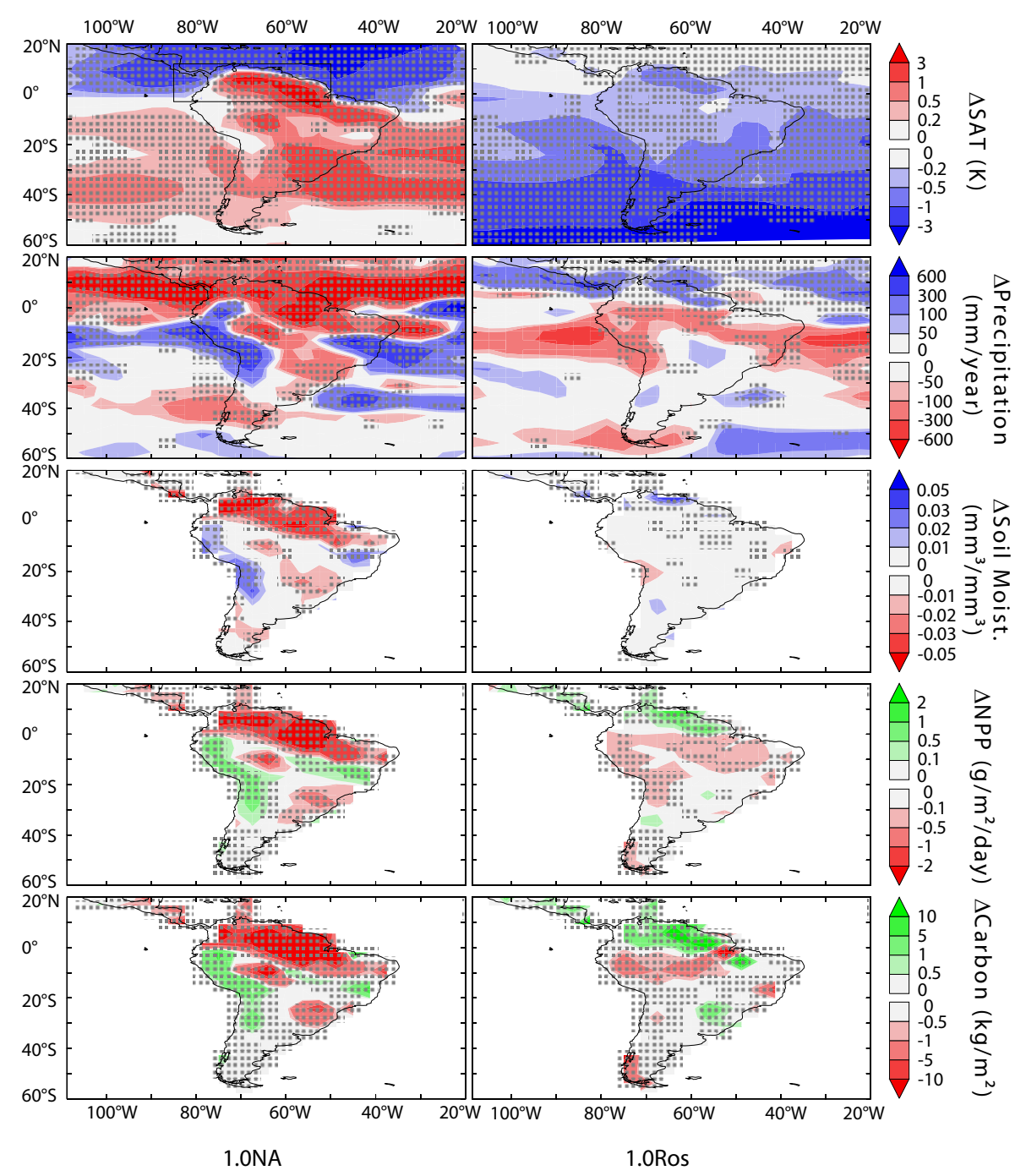

Fig. 8. Snapshots of the anomalies of various climatic variables and terrestrial carbon by the end of the perturbation (decadal average) for the experiments 1.0 NA (left column) and 1.0 Ros (right column). Anomalies are calculated as the 97-106 years of experiments minus the 100-year averaged Control. The variables shown from top to bottom are as follows, SAT $\left({ }^{\circ} \mathrm{C}\right)$, precipitation $\left(\mathrm{mm}^{-1}{ }^{-1}\right)$, soil moisture $\left(\mathrm{mm}^{3} \mathrm{~mm}^{-3}\right)$, NPP $\left(\mathrm{g} \mathrm{m}^{-2} \mathrm{day}^{-1}\right)$ and Total Carbon $\left(\mathrm{kg} \mathrm{m}^{-2}\right)$. Stippled areas indicate where the ensemble mean anomaly is significantly different from zero at the $67 \%$ level (Student's t-Test).

\subsection{Comparison of South American paleoclimate reconstructions with the model results}

A comparison of several paleoclimate reconstructions of precipitation anomalies during the Younger Dryas period (Table 3) with our model results shows a good agreement between proxy records and the 1.0 NA experiment responses in most locations (Fig. 11), which supports the robustness of the ITCZ-shift hypothesis and the existence of a dipole relation between the north of the continent and eastern and southern Brazil, as suggested by Wang et al. (2007). Such a dipole seems to exist between the north and the west of the continent too (Martin et al., 1997). This increase in precipitation in the west of the continent is also apparent in the proxy records. Differences in the boundaries of the precipitation increase and decrease exist, yet it should be kept in mind that the ability of the model to make regional predictions is limited by its resolution.

Overall, the difference in behaviour of the global carbon cycle, together with the site-specific responses in South America give us a way to interpret the origin of the freshwater input. Thus, for future reconstruction studies considering the anti-phase relationship between different parts of the continent and also the opposite responses to the origin of the freshwater input should help us obtain a clearer picture of what has actually happened during such events. 


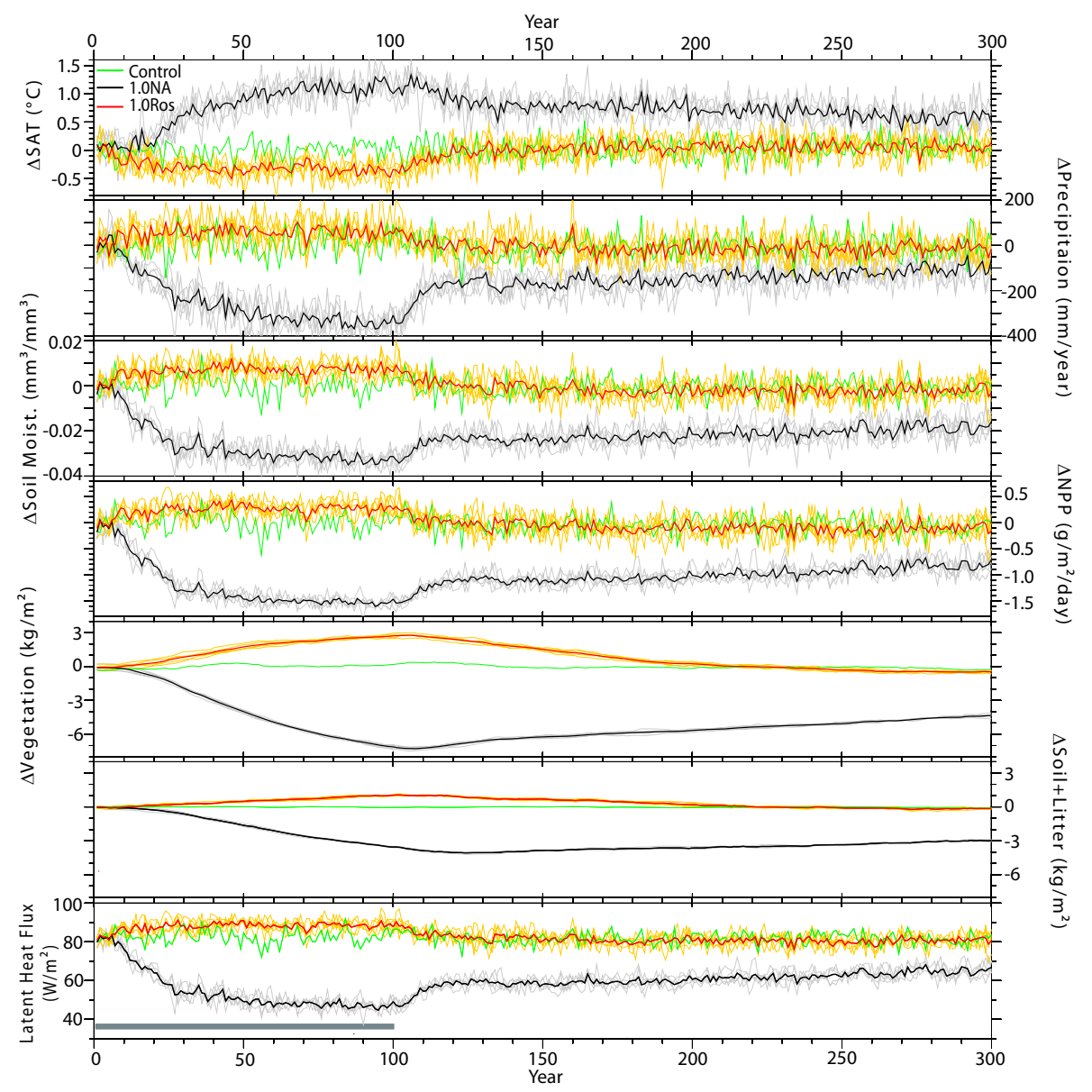

Fig. 9. Time evolution of the changes in the northern part of South America (the region marked in Fig. 8, top left panel). From top to bottom are shown the anomalies in SAT $\left({ }^{\circ} \mathrm{C}\right)$, precipitation $\left(\mathrm{mm} \mathrm{yr}^{-1}\right)$, soil moisture $\left(\mathrm{mm}^{3} \mathrm{~mm}^{-3}\right)$, NPP $\left(\mathrm{g} \mathrm{m}^{2}\right.$ day $\left.{ }^{-1}\right)$, Vegetation Carbon $\left(\mathrm{kg} \mathrm{m}^{-2}\right)$, Soil and Litter Carbon $\left(\mathrm{kg} \mathrm{m}^{-2}\right)$, and Latent Heat Flux $\left(\mathrm{W} \mathrm{m}^{-2}\right)$. The green curve is the Control and the black and red curves are the ensemble averages of the 1.0 NA the 1.0 Ros experiments, respectively. The thin grey and orange curves are the individual ensemble members of the respective experiment. The grey bar at the bottom marks the duration of the freshwater input.

\section{Discussion and conclusions}

In our model simulations the response of the climate and the land biosphere to a collapse or a reduction in the AMOC can be divided into two categories according to where the freshwater perturbation is applied. All the perturbations from the North Atlantic Deep Water formation region cause similar responses, which are opposite to those caused by the perturbations from the Weddell Sea and the Ross Sea. Weddell Sea and Ross Sea responses are also different from each other, Ross Sea creating a much more widespread cooling and a clearer precipitation signal. That seems to be because the Ross Sea is a more important player in the creation of the AABW in our model than the Weddell Sea and, therefore, the perturbation in the Ross Sea has a stronger effect on the global climate. We note, however, that the specific locations of deep water formation are model dependent.
The most significant changes in precipitation occur around the tropics near the ITCZ, whose position is sensitive to shifts in SST. This, in turn, creates large changes in the carbon stocks in these locations. Additionally, the fact that large amounts of carbon are stored in low latitudes causes these precipitation anomalies to amplify changes in carbon stocks. Köhler et al. (2005) forced the Lund-Potsdam-Jena (LPJ) model with an output from freshwater experiments with the ECBILT-CLIO model. They found large changes in carbon stocks in the boreal zone and relatively small carbon stock changes in the tropics in contrast to our results. There are a variety of differences between the two studies. Vegetation dynamics is explicitly simulated in the LPJ, whereas vegetation distribution is prescribed in the NCAR CSM1.4carbon model. On the other hand, interactions and feedbacks between vegetation and climate, such as those related to albedo and the water cycle, are represented in the coupled NCAR model, but not in the forced runs with LPJ. The 




Fig. 10. Wind velocity $\left(\mathrm{m} \mathrm{s}^{-1}\right)$ at $800 \mathrm{mbar}$ for the Control (100-year average, top) and the anomaly at years $97-106$ in $1.0 \mathrm{NA}$ (bottom). The reference vector is $25 \mathrm{~m} \mathrm{~s}^{-1}$ for Control and $5 \mathrm{~m} \mathrm{~s}^{-1}$ for the $1.0 \mathrm{NA}$ anomaly.

atmospheric dynamics in the cost-efficient ECBILT-CLIO is represented in a simplified manner which limits its ability to simulate dynamics in the tropics.

While the southward shift of the ITCZ after the northern perturbations is well studied with climate models and supported by paleoclimate records (Leduc et al., 2009), we show that the opposite is also true, that is to say, the northward shift of the ITCZ in response to a southern perturbation. Moreover, this has direct consequences for the tropical rainforest type of vegetation in that region. The very direction of this shift determines the direction of the change in the atmospheric $\mathrm{CO}_{2}$ concentration through its effects on the land carbon pool in the low latitudes.
The magnitude of $\mathrm{CO}_{2}$ increase during the Heinrich events and also during the Younger Dryas event was around 20 ppmv, as recorded in ice-cores (Indermühle et al., 2000; Monnin et al., 2001). According to our results, all of this amplitude can be explained by the carbon release from the land biosphere while the ocean acts as a carbon sink. The isotopic signature of the $\mathrm{CO}_{2}$ from the ice cores also points to a land origin for the increase during Younger Dryas (Smith et al., 1999). Moreover, in a recent comprehensive simulation of the last deglaciation, covering the Heinrich Event 1 (H1), with a coupled atmosphere-ocean general circulation model, Liu et al. (2009) successfully reproduced the major features of this cooling event. They found strong cooling 
Table 2. A selection of regions that have recorded considerable changes given with their land area, the limits defined and the change of total carbon stocks in that area by the year 101 (end of the perturbation). $0.5 \mathrm{NA}$ and $0.3 \mathrm{NA}$ experiments are also included in the list for the purpose of comparison.

\begin{tabular}{|c|c|c|c|c|c|c|c|}
\hline \multirow[t]{2}{*}{ Regions } & \multirow[t]{2}{*}{ Area } & \multirow{2}{*}{$\begin{array}{r}\text { Size } \\
\left(10^{6} \mathrm{~km}^{2}\right)\end{array}$} & \multicolumn{5}{|c|}{ Change of Total Carbon (GtC) } \\
\hline & & & $1.0 \mathrm{NA}$ & $0.5 \mathrm{NA}$ & $0.3 \mathrm{NA}$ & 1.0 Ros & $1.0 \mathrm{Wed}$ \\
\hline $\begin{array}{l}\text { Northern } \\
\text { Europe }\end{array}$ & $\begin{array}{l}13^{\circ} \mathrm{W}-28^{\circ} \mathrm{E} \\
50^{\circ} \mathrm{N}-65^{\circ} \mathrm{N}\end{array}$ & 2.04 & -3.34 & -3.35 & -2.58 & -0.16 & -0.27 \\
\hline $\begin{array}{l}\text { Northern } \\
\text { North America }\end{array}$ & $\begin{array}{l}51^{\circ} \mathrm{W}-160^{\circ} \mathrm{W} \\
50^{\circ} \mathrm{N}-65^{\circ} \mathrm{N}\end{array}$ & 7.02 & -4.58 & -4.00 & -2.92 & -0.68 & -0.40 \\
\hline $\begin{array}{l}\text { Northern } \\
\text { South America }\end{array}$ & $\begin{array}{l}50^{\circ} \mathrm{W}-84^{\circ} \mathrm{W} \\
1^{\circ} \mathrm{S}-10^{\circ} \mathrm{N}\end{array}$ & 3.14 & -42.86 & -29.16 & -13.75 & 15.20 & 10.10 \\
\hline Africa & $\begin{array}{l}15^{\circ} \mathrm{W}-30^{\circ} \mathrm{E} \\
18^{\circ} \mathrm{S}-18^{\circ} \mathrm{N}\end{array}$ & 12.26 & 10.05 & 6.17 & 1.16 & 5.54 & 7.43 \\
\hline Southeast Asia & $\begin{array}{l}90^{\circ} \mathrm{E}-150^{\circ} \mathrm{E} \\
14^{\circ} \mathrm{S}-22^{\circ} \mathrm{N}\end{array}$ & 5.88 & 9.44 & 5.73 & 2.76 & -0.31 & -1.78 \\
\hline Other & & 119.26 & -37.35 & -21.27 & -7.28 & -5.45 & -2.22 \\
\hline Total land & & 149.6 & -68.64 & -45.88 & -22.61 & 14.14 & 12.86 \\
\hline
\end{tabular}

Table 3. List of the paleoclimate reconstruction studies of precipitation change in and around South America during the Younger Dryas event, as used in the compilation given in Fig. 11. Reconstructed anomalies during Younger Dryas are given in comparison with our model results from the experiment 1.0 NA. A wide range of climate proxies are used in these reconstructions including, marine sediments, lake sediments, ice cores and speleothems. Pollen records as written in parenthesis are indicative of a change in the vegetation. These are shown in the figure as squares to distinguish from the rest of the proxies (circles).

\begin{tabular}{llllll}
\hline$\#$ & Location & Proxy & Model & Proxy Type & Reference \\
\hline 1 & Ceara Rise, Brazil & wet & dry & Marine sediment (Ti/Ca, Fe/Ca) & Arz et al. (1998) \\
2 & Lake Titicaca, Bolivia and Peru & wet & wet & Lake sediment & Baker et al. (2001) \\
3 & Atacama Desert, Chile & wet & wet & Fossil rodent middens & Betancourt et al. (2000) \\
4 & La Yeguada, Panama & dry & dry & Lake sediment (charcoal) & Bush et al. (1992) \\
5 & Laguna de Chochos, Peru & dry & wet & Lake sediment (pollen) & Bush et al. (2005) \\
6 & Botuverá Cave, Brazil & wet & dry & Speleothem & Cruz et al. (2005) \\
7 & Laguna Baja, Peru & dry & wet & Lake sediment (pollen) & Hansen and Rodbell (1995) \\
8 & Cariaco Basin, Venezuela & dry & dry & Marine sediment (Ti/Ca, Fe/Ca) & Haug et al. (2001) \\
9 & Cariaco Basin, Venezuela & dry & dry & Marine sediment (bio-markers) & Hughen et al. (2004) \\
10 & NE Brazil & wet & dry & Marine sediment & Jennerjahn et al. (2004) \\
11 & Lagoa do Caçó, Brazil & dry & dry & Lake sediment(pollen) & Ledru et al. (2002) \\
12 & Amazon Basin & dry & dry & Marine sediment (planktonic $\delta{ }^{18}$ O) & Maslin and Burns (2000) \\
13 & Heulmo mire, Chile & dry & dry & Lake sediment (pollen) & Massaferro et al. (2009) \\
14 & Lago Condorito, Chile & dry & dry & Lake sediment (pollen) & Moreno (2000) \\
15 & Offshore-Lima, Peru & wet & wet & Marine sediment & Rein et al. (2005) \\
16 & Serra dos Carajas, Brazil & wet & dry & Lake sediment (pollen) & Servant et al. (1999) \\
17 & Salitre, Brazil & dry & dry & Lake sediment (pollen) & Servant et al. (1999) \\
18 & Colombia & dry & dry & Lake sediment (pollen) & van't Veer et al. (2000) \\
19 & Lapa dos Brejões and & wet & wet & Speleothem & Wang et al. (2004) \\
& Toca da Barriguda caves, Brazil & & & &
\end{tabular}




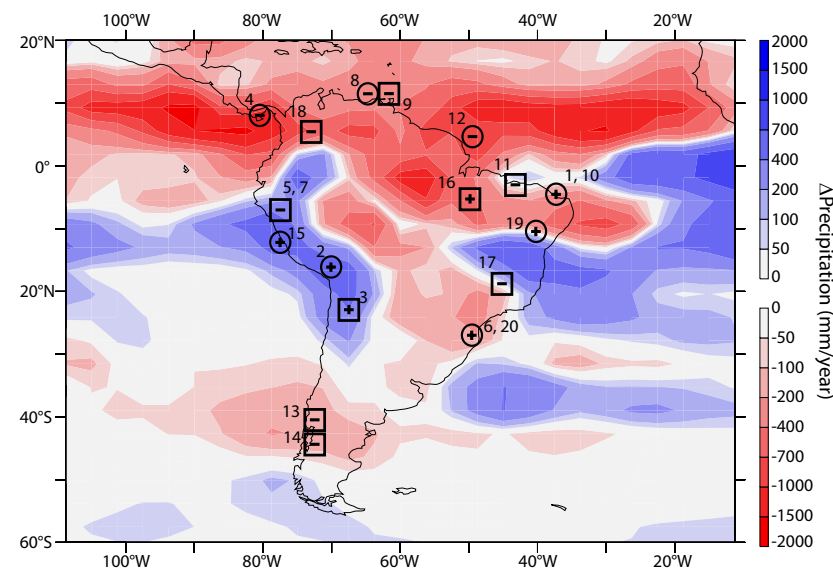

Fig. 11. Compilation of different reconstructions showing precipitation and vegetation changes in South America during the Younger Dryas event (ca. $12 \mathrm{kyr} \mathrm{BP}$ ). Plus (+) sign indicates dryer conditions during the event and minus $(-)$ sign wetter. Square frames around the signs are used for vegetation proxies, whereas circle frames are for precipitation proxies in general. The colour shading in the background shows the 10-year average annual precipitation anomaly by the end of the perturbation in the experiment 1.0 NA. The numbering of the studies is as follows: 1. Arz et al. (1998), 2. Baker et al. (2001), 3. Betancourt et al. (2000), 4. Bush et al. (1992), 5. Bush et al. (2005), 6. Cruz et al. (2005), 7. Hansen and Rodbell (1995), 8. Haug et al. (2001), 9. Hughen et al. (2004), 10. Jennerjahn et al. (2004), 11. Ledru et al. (2002), 12. Maslin and Burns (2000), 13. Massaferro et al. (2009), 14. Moreno (2000), 15. Rein et al. (2005), 16-17. Servant et al. (1999), 18. van't Veer et al. (2000), 19. Wang et al. (2004), 20. Wang et al. (2007).

in the Northern Hemisphere with a milder warming in the south, and reduced precipitation in the Cariaco basin (northern South America). The good agreement of the general patterns of change indicates that a comparison of a paleoclimate event under glacial conditions (H1) and our simulations under pre-industrial conditions is reasonable.

The net atmospheric $\mathrm{CO}_{2}$ increase in our experiments is comparable to, but more than, that of Obata (2007) with similar initial conditions. Even though the changes in the climatic variables and the NPP show a strong resemblance, their magnitudes differ in some areas. These include a more wide-spread cooling in the Northern Hemisphere in our experiments, and a smaller land biosphere response to the precipitation anomalies in eastern Asia. Additionally, a larger negative anomaly is recorded in northern part of South America in our study. Yet, the general effect of the ITCZ-shift is robust in both studies. The differences may be attributed to the more limited representation of the land biosphere in the model used by Obata (2007).

The exact amount of the contribution of the land biosphere to this atmospheric $\mathrm{CO}_{2}$ increase, however, should be taken with caution since the glacial vegetation cover on land was different than that implemented here. Our experiments are done under pre-industrial conditions with a larger vegetation carbon pool than during the glacial times. In a previous study (Menviel et al., 2008), in which the experiments were done under both pre-industrial and glacial boundary conditions, it has been shown that the differences in the amplitudes of the individual contributions from the land and ocean carbon pools may lead to an opposite net effect on the atmospheric $\mathrm{CO}_{2}$, even though the nature of each contribution is qualitatively the same. In their study, irrespective of the initial state, the roles of the ocean as a carbon sink and of the land as a carbon source remain unchanged. Also, the changes on land are very similar in both cases, that is, a reduction in the carbon stocks in the high and mid-latitudes of the Northern Hemisphere and in the tropics north of the equator and an increase to the south. Yet, the emissions from land under glacial conditions are weaker than under the pre-industrial conditions. That is probably due to the lower moisture content of the glacial atmosphere, which leads to the dampening effects of the ITCZ shift (Menviel et al., 2008), and relatively large gains in primary production in some regions such as eastern Asia and southern North America. Compared to our experiments, the main differences are the larger increases in carbon stocks in the Southern Hemisphere and the abovementioned regions in the north, which might be due to some model specific differences as well as the initial conditions.

Nevertheless, as the patterns of the anomalies are very similar in both studies, it is safe to assume that our results are relevant for paleo-reconstructions as a possible indirect way to distinguish between the sources of freshwater discharge in abrupt cooling events, because the northern Atlantic and Antarctic perturbations have distinct implications for the land biosphere. Globally, the atmospheric $\mathrm{CO}_{2}$ signal is different; an increase for the North Atlantic case and a decrease for the Antarctic case. Regionally, the South American continent proves to be in a particularly suitable position to record such past events, as the movement of the ITCZ - either to the south or to the north - would create distinguishable and, at some places, opposite responses.

In addition to what has been presented in the results section, there are some other notable features that are observed in response to the freshwater perturbations, such as the North Pacific Deep Water formation, or the strengthening of Southern Hemispheric westerlies (Fig. 10). A more detailed investigation of those responses may be undertaken in a future study.

The results of this study have also implications for future anthropogenic climate change which, as many modelling studies show, is to cause a reduction in the AMOC (Meehl et al., 2007). The effects of such a reduction can be substantial for climate and for low latitude ecosystems including, but not limited to, the rain-forests. It is also important to note that, the changes in the carbon cycle during such an event would possibly contribute to the increase in the atmospheric carbon and hence, operate as a weak positive feedback to the global warming, in addition to that associated with outgassing from a warmer ocean (Joos et al., 1999). 
Acknowledgements. This study was funded by the Swiss National Science Foundation and the support by the project Past4Future is also acknowledged. Simulations were carried out at the Swiss National Supercomputing Centre in Manno, Switzerland. We thank S. C. Doney, I. Fung, K. Lindsay, J. John and colleagues for providing the CSM1.4-carbon code and M. Grosjean for advice on the South American paleo-records. We also thank the two anonymous reviewers and $\mathrm{H}$. Hooghiemstra for their constructive comments.

Edited by: A. Sluijs

\section{References}

Ammann, B., Birks, H. J. B., Brooks, S. J., Eicher, U., von Grafenstein, U., Hofmann, W., Lemdahl, G., Schwander, J., Tobolski, K., and Wick, L.: Quantification of biotic responses to rapid Climatic Changes around the Younger Dryas: A synthesis, Palaeogeogr. Palaeocl., 159, 313-347, 2000.

Arz, H. W., Patzold, J., and Wefer, G.: Correlated millennial-scale changes in surface hydrography and terrigenous sediment yield inferred from last-glacial marine deposits off northeastern Brazil, Quaternary Res., 50, 157-166, 1998.

Baker, P. A., Seltzer, G. O., Fritz, S. C., Dunbar, R. B., Grove, M. J., Tapia, P. M., Cross, S. L., Rowe, H. D., and Broda, J. P.: The History of South American Tropical Precipitation for the Past 25000 Years, Nature, 291, 640-643, 2001.

Barber, D. C., Dyke, A., Hillaire-Marcel, C., Jenninngs, A. E., Andrews, J. T., Kerwin, M. W., Bilodeau, G., McNeely, R., Southon, J., Morehead, M. D., and Gagnon, J.-M.: Forcing of the cold event of 8200 years ago by catastrophic drainage of Laurentide lakes, Nature, 400, 344-348, 1999.

Bard, E.: Climate Shock: Abrupt Changes over Millennial Time Scales, Phys. Today, 55, 32-39, 2002.

Barker, S., Diz, P., Vautravers, M. J., Knorr, J. P. G., Hall, I. R., and Broecker, W. S.: Interhemispheric Atlantic seesaw response during the last deglaciation, Nature, 457, 1097-1102, 2009.

Betancourt, J. L., Latorre, C., Rech, J. A., Quade, J., and Rylander, K. A.: A 22,000-Year Record of Monsoonal Precipitation from Northern Chile's Atacama Desert, Science, 289, 15421546, 2000.

Bonan, G. B.: The NCAR land surface model (LSM version 1.0) coupled to the NCAR Community Climate Model, Tech. rep., 1996.

Bond, G., Broecker, W., Johnsen, S., McManus, J., Labeyrie, L., Jouzel, J., and Bonani, G.: Correlations between climate records from North Atlantic sediments and Greenland ice, Nature, 365, 143-147, 1993.

Boville, B. A. and Gent, P. R.: The NCAR Climate System Model, Version One, J. Climate, 11, 1115-1130, 1999.

Boyle, E. A. and Keigwin, L. D.: North Atlantic thermohaline circulation during the past 20000 ears linked to high latitude surface temperature, Nature, 330, 35-40, 1987.

Broecker, W. S.: Thermohaline Circulation, the Achilles Heel of Our Climate System: Will Man-Made $\mathrm{CO}_{2}$ Upset the Current Balance?, Science, 278, 1582-1588, 1997.

Bryan, F.: High-latitude salinity effects and interhemispheric thermohaline circulations, Nature, 323, 301-304, 1986.
Bush, M. B., Piperno, D. R., Colinvaux, P. A., Oliveira, P. E. D., Krissek, L. A., Miller, M. C., and Rowe, W. E.: A 14300-Yr Paleoecological Profile of a Lowland Tropical Lake in Panama, Ecol. Monogr., 62, 251-275, 1992.

Bush, M. B., Hansen, B. C. S., Rodbell, D. T., Seltzer, G. O., Young, K. R., León, B., Abbott, M. B., Silman, M. R., and Gosling, W. D.: A 17000 -year history of Andean climate and vegetation change from Laguna de Chochos, Peru, J. Quaternary Sci., 20, 703-714, 2005.

Chiang, J. C. H.: The Tropics in Paleoclimate, Annu. Rev. Earth Pl. Sc., 37, 263-297, 2009.

Clark, P. U., Pisias, N. G., Stocker, T. F., and Weaver, A. J.: The role of the thermohaline circulation in abrupt climate change, Nature, 415, 863-869, 2002.

Clement, A. C. and Peterson, L. C.: Mechanisms of abrupt climate change of the last glacial period, Rev. Geophys., 46, RG4002, doi:10.1029/2006RG000204, 2008.

Cruz, F. W., Burns, S. J., Karmann, I., Sharp, W. D., Vuille, M., Cardoso, A. O., Ferrari, J. A., Silva Dias, P. L., and Viana, O.: Insolation-driven changes in atmospheric circulation over the past 116000 years in subtropical Brazil, Nature, 434, 63-65, 2005.

Cruz, F. W., Vuille, M., Burns, S. J., Wang, X., Cheng, H., Werner, M., Edwards, R. L., Karmann, I., Auler, A. S., and Nguyen, H.: Orbitally driven east-west antiphasing of South American precipitation, Nat. Geosci., 2, 210-214, 2009.

Dahl, K. A., Broccoli, A. J., and Stouffer, R. J.: Assessing the role of North Atlantic freshwater forcing in millennial scale climate variability: a tropical Atlantic perspective, Clim. Dynam., 24, 325-346, 2005.

Dansgaard, W., Johnson, S. J., Clausen, H. B., Dahl-Jensen, D., Gundestrup, N., Hammer, C. H., and Oeschger, H.: North Atlantic oscillations revealed by deep Greenland ice cores, Climate Processes and Climate Sensitivity, Geophys. Monogr., 29, 288298, 1984.

Ding, Z. L., Ren, J. Z., Yang, S. L., and Liu, T. S.: Climate instability during the penultimate glaciation: evidence from two highresolution loess records, China, J. Geophys. Res., 104, 2012320132, 1999.

Doney, S. C., Lindsay, K., Fung, I., and John, J.: Natural Variability in a Stable, 1000-Yr Global Coupled Climate-Carbon Cycle Simulation, J. Climate, 19, 3033-3054, 2006.

Duplessy, J. C., Shackleton, N. J., Fairbanks, R. G., Labeyrie, L., and Oppo, D. W.: Deepwater source variations during the last climatic cycle and their impact on the global deepwater circulation, Paleoceanography, 3, 343-360, 1988.

Dupont, L. M., Schlutz, F., Ewah, C. T., Jennerjahn, T. C., Paul, A., and Behling, H.: Two-step vegetation response to enhanced precipitation in Northeast Brazil during Heinrich event 1, Global Change Biol., 16, 1647-1660, 2010.

Eicher, U., Siegenthaler, U., and Wegmueller, S.: Pollen and isotope analysis on late and post-glacial sediments of the Tourbiere de Chirens (Dauphine, France), Quaternary Res., 15, 160-170, 1981.

EPICA Community Members: One-to-one coupling of glacial climate variability in Greenland and Antarctica, Nature, 444, 195198, 2006. 
Friedlingstein, P., Joel, G., Field, C. B., and Fung, I. Y.: Toward an allocation scheme for global terrestrial carbon models, GlobAL Change Biol., 5, 755-770, 1999.

Frölicher, T. L. and Joos, F.: Reversible and irreversible impacts of greenhouse gas emissions in multi-century projections with the NCAR global coupled carbon cycle-climate model, Clim. Dynam., 1-21, 2010.

Frölicher, T. L., Joos, F., Plattner, G.-K., Steinacher, M., and Doney, S. C.: Natural variability and anthropogenic trends in oceanic oxygen in a coupled carbon cycle-climate model ensemble, Global Biogeochem. Cy., 23, GB1003, doi:10.1029/2008GB003316, 2009.

Fung, I., Doney, S. C., Lindsay, K., and John, J.: Evolution of carbon sinks in a changing climate, P. Natl. Acad. Sci. USA, 102, 11201-11206, 2005.

Gent, P. R., Bryan, F. O., Danabasoglu, G., Doney, S. C., Holland, W. R., Large, W. G., and McWilliams, J. C.: The NCAR Climate System Model Global Ocean Component, J. Climate, 11, 12871306, 1998.

Hansen, B. C. S. and Rodbell, D. T.: A Late-Glacial/Holocene Pollen Record from the Eastern Andes of Northern Peru, Quaternary Res., 44, 216-227, 1995.

Haug, G. H., Hughen, K. A., Sigman, D. M., Peterson, L. C., and Rohl, U.: Southward migration of the intertropical convergence zone through Holocene, Science, 293, 1304-1308, 2001.

Heinrich, H.: Origin and consequences of cyclic ice rafting in the northeast Atlantic ocean during the past 130000 years, Quaternary Res., 29, 142-152, 1988.

Hemming, R. S.: Heinrich events: Massive late Pleistocene detritus layers of the North Atlantic and their global climate imprint, Rev. Geophys., 42, RG1005, doi:10.1029/2003RG000128, 2004.

Huber, C., Leuenberger, M., Spahni, R., Fluckiger, J., Schwander, J., Stocker, T. F., Johnsen, S., Landals, A., and Jouzel, J.: Isotope calibrated Greenland temperature record over Marine Isotope Stage 3 and its relation to CH4, Earth Planet. Sc. Lett., 243, 504-519, 2006.

Hughen, K. A., Southon, J. R., Lehman, S. J., and Overpeck, J. T.: Synchronous radiocarbon and climate shifts during the last deglaciation, Science, 290, 1951-1954, 2000.

Hughen, K. A., Eglinton, T. I., Xu, L., and Makou, M.: Abrupt tropical vegetation response to rapid climate changes, Science, 304, 1955-1959, 2004.

Indermühle, A., Monnin, E., Stauffer, B., Stocker, T. F., and Wahlen, M.: Atmospheric $\mathrm{CO}_{2}$ concentration from 60 to 20 kyr BP from the Taylor Dome Ice Core, Antarctica, Geophys. Res. Lett., 27, 735-738, 2000.

Jennerjahn, T. C., Ittekkot, V., Arz, H. W., Behling, H., Patzold, J., and Wefer, G.: Asynchronous Terrestrial and Marine Signals of Climate Change During Heinrich Events, Science, 306, 22362239, 2004.

Joos, F., Plattner, G.-K., Stocker, T. F., Marchal, O., and Schmittner, A.: Global warming and marine carbon cycle feedbacks on future atmospheric $\mathrm{CO}_{2}$, Science, 284, 464-467, 1999.

Kiehl, J. T., Hack, J. J., Bonan, G. B., Boville, B. A., Williamson, D. L., and Rasch, P. J.: The National Center for Atmospheric Research Community Climate Model: CCM3, J. Climate, 11, 1131-1149, 1998.
Knutti, R., Flueckiger, J., Stocker, T. F., and Timmermann, A.: Strong hemispheric coupling of glacial climate through freshwater discharge and ocean circulation, Nature, 430, 851-856, 2004.

Köhler, P., Joos, F., Gerber, S., and Knutti, R.: Simulated changes in vegetation distribution, land carbon storage, and atmospheric $\mathrm{CO}_{2}$ in response to a collapse of the North Atlantic thermohaline circulation, Clim. Dynam., 25, 689-708, 2005.

Ledru, M.-P., Mourguiart, P., Ceccantini, G., Turcq, B., and Sifeddine, A.: Tropical climates in the game of two hemispheres revealed by abrupt Climatic Change, Geology, 30, 275-278, 2002.

Leduc, G., Vidal, L., Tachikawa, K., and Bard, E.: ITCZ rather than ENSO signature for abrupt climate changes across the tropical Pacific?, Quaternary Res., 72, 123-131, 2009.

Levermann, A., Griesel, A., Hofmann, M., Montoya, M., and Rahmstorf, S.: Dynamic sea level changes following changes in the thermohaline circulation, Clim. Dynam., 24, 347-354, 2005.

Liu, Z., Otto-Bliesner, B. L., He, F., Brady, E. C., Tomas, R., Clark, P. U., Carlson, A. E., Lynch-Stieglitz, J., Curry, W., Brook, E., Erickson, D., Jacob, R., Kutzbach, J., and Cheng, J.: Transient Simulation of Last Deglaciation with a New Mechanism for Bølling-Allerød Warming, Science, 325, 310-314, 2009.

Manabe, S. and Stouffer, R. J.: The role of thermohaline circulation in climate, Tellus A, 51, 91-109, 1999.

Marchal, O., Stocker, T. F., and Joos, F.: Impact of Oceanic Reorganizations on the Ocean Carbon Cycle and Atmospheric Carbon Dioxide Content, Paleoceanography, 15, 341-354, 1998.

Marchal, O., Stocker, T. F., Joos, F., Indermühle, A., Blunier, T., and Tschumi, J.: Modeling the concentration of atmospheric $\mathrm{CO}_{2}$ during the Younger Dryas climate event, Clim. Dynam., 15, 341354, 1999.

Martin, L., Bertaux, J., Corrège, T., Ledru, M.-P., Mourguiart, P., Sifeddine, A., Soubiès, F., Wirrmann, D., Suguio, K., and Turcq, B.: Astronomical Forcing of Contrasting Rainfall Changes in Tropical South America between 12,400 and 8800 cal yr B.P., Quaternary Res., 47, 117-122, 1997.

Maslin, M. A. and Burns, S. J.: Reconstruction of the Amazon Basin effective moisture availability over the past 14000 years, Science, 290, 2285-2287, 2000.

Massaferro, J., Moreno, P., Denton, G., Vandergoes, M., and Dieffenbacher-Krall, A.: Chironomid and pollen evidence for climate fluctuations during the Last Glacial Termination in NW Patagonia, Quaternary Sci. Rev., 28, 517-525, 2009.

Meehl, G. A., Stocker, T. F., Collins, W. D., Friedlingstein, P., Gaye, A. T., Gregory, J. M., Kitoh, A., Knutti, R., Murphy, J. M., Noda, A., Raper, S. C. B., Watterson, I. G., Weaver, A. J., and Zhao, Z.-C.: Global Climate Projections, in: Climate Change 2007: The Physical Science Basis. Contribution of Working Group I to the Fourth Assessment Report of the Intergovernmental Panel on Climate Change, Cambridge University Press, Cambridge, UK and New York, NY, USA, 2007.

Menviel, L., Timmermann, A., Mouchet, A., and Timm, O.: Meridional reorganizations of marine and terrestrial productivity during Heinrich events, Paleoceanography, 23, PA1203, doi:10.1029/2007PA001445, 2008.

Menviel, L., Timmermann, A., Timm, O., and Mouchet, A.:Climate and biogeochemical response to a rapid melting of the West Antarctic Ice Sheet during interglacials and implications for future climate, Paleoceanography, 25, PA4231, doi:10.1029/2009PA001892, 2010 
Menviel, L., Timmermann, A., Timm, O., and Mouchet, A.:Deconstructing the last Glacial Termination: the role of millennial and orbital-scale forcings, Quaternary Sci. Rev., JQSR2995, doi:10.1016/j.quascirev.2011.02.005, in press, 2011.

Mikolajewicz, U.: A meltwater-induced collapse of the "conveyor belt" thermohaline circulation and its influence on the distribution of $\Delta^{14} C$ and $\delta^{18} O$ in the oceans, vol. 189 of Technical Report, Tech. rep., Hamburg, Germany, 1996.

Mikolajewicz, U., Crowley, J. C., Schiller, J. C., and Voss, R.: Modeling teleconnections between the North Atlantic and North Pacific during the Younger Dryas, Nature, 387, 384-387, 1997.

Monnin, E., Indermuehle, A., Daellenbach, A., Flueckiger, J., Stauffer, B., Stocker, T. F., Raynaud, D., and Barnola, J.-M.: Atmospheric $\mathrm{CO}_{2}$ Concentrations over the Last Glacial Termination, Science, 291, 112-114, 2001.

Moreno, P. I.: Climate, Fire, and Vegetation between About 13,000 and $9200{ }^{14} C$ yr B.P. in the Chilean Lake District, Quaternary Res., 54, 81-89, 2000.

Muscheler, R., Beer, J., Wagner, G., and Finkel, R. C.: Changes in deep-water formation during the Younger Dryas event inferred from ${ }^{10} \mathrm{Be}$ and ${ }^{14} \mathrm{C}$ records, Nature, 408, 567-570, 2000.

Najjar, R. G., Sarmiento, J. L., and Toggweiler, J. R.: Downward Transport and Fate of Organic Matter in the Ocean: Simulations with a General Circulation Model, Global Biogeochem. Cy., 6, 45-76, 1992.

NorthGRIP Members: High-resolution climate record of the Northern Hemisphere back into the last glacial interglacial period, Nature, 431, 147-151, 2004.

Obata, A.: Climate-Carbon Cycle Model Response to Freshwater Discharge into the North Atlantic, J. Climate, 20, 5962-5976, 2007.

Oeschger, H., Beer, J., Siegenthaler, U., and Stauffer, B.: Late glacial climate history from ice cores, in: Geophysical Monograph, edited by: Hansen, J. E. and Takahashi, T., American Geophysical Union, Washington, DC, 29, 299-306, 1984.

Okazaki, Y., Timmermann, A., Menviel, L., Harada, N., AbeOuchi, A., Chikamoto, M., Mouchet, A., and Asahi, H.: Deep water formation in the North Pacific during the Last Glacial termination, Science, 329, 200-204, 2010.

Okumura, Y. M., Deser, C., Hu, A., Timmermann, A., and Xie, S.P.: North Pacific Climate Response to Freshwater Forcing in the Subarctic North Atlantic: Oceanic and Atmospheric Pathways, J. Climate, 22, 1424-1445, 2009.

Porter, S. C.: Chinese loess record of monsoon climate during the last glacial-interglacial cycle, Earth Sci. Rev., 54, 115-128, 2001.

Prokopenko, A. A., Williams, D. F., Karabanov, E. B., and Khursevich, G. K.: Continental response to Heinrich events and Bond cycles in sedimentary record of Lake Baikal, Siberia, Global Planet. Change, 28, 217-226, 2001.

Rahmstorf, S.: Ocean circulation and climate during the past 120000 years, Nature, 419, 207-214, 2002.

Randerson, J., Thompson, M., Conway, T., Fung, I., and Field, C.: The Contribution of Terrestrial Sources and Sinks to Trends in the Seasonal Cycle of Atmospheric Carbon Dioxide, Global Biogeochem. Cy., 11, 535-560, 1997.

Rein, B., Lückge, A., Reinhardt, L., Sirocko, F., Wolf, A., and Dullo, W.-C.: El Niño variability off Peru during the last 20000 years, Paleoceanography, 20, PA4003, doi:10.1029/2004PA001099, 2005.
Rousseau, D. D., Antoine, P., Hatte, C., Lang, A., Zoller, L., Fontugne, M., Othman, D. B., Luck, J. M., Moine, O., Labonne, M., Bentaleb, I., and Jolly, D.: Abrupt millennial Climatic Changes from Nussloch (Germany) upper Weichselian eolian records during the last glaciation, Quaternary Sci. Rev., 21, 1577-1582, 2002.

Ruddiman, W. F. and McIntyre, A.: The North Atlantic Ocean during the last glaciation, Palaeogeogr. Palaeocl., 35, 145-214, 1981.

Schiller, A., Mikolajewicz, U., and Voss, R.: The stability of the North Atlantic thermohaline circulation in a coupled oceanatmosphere general circulation model, Clim. Dynam., 13, 325357, 1997.

Schmittner, A.: Decline of the marine ecosystem caused by a reduction in the Atlantic overturning circulation, Nature, 434, 628633, 2005.

Schmittner, A. and Galbraith, E. D.: Glacial greenhouse-gas fluctuations controlled by ocean circulation changes, Nature, 456, 373-376, 2008.

Sellers, P., Randall, D., Collatz, G., Berry, J., Field, C., Dazlich, D., Zhang, C., Collelo, G., and Bounoua, L.: A Revised Land Surface Parametrization $\left(\mathrm{SiB}_{2}\right)$ for Atmospheric GCMS, Part I: Model Formulation, J. Climate, 9, 676-705, 1996.

Servant, M., Maley, J., Turcq, B., Absy, M.-L., Brenac, P., Fournier, M., and Ledru, M.-P.: Tropical forest changes during the Late Quaternary in African and South American lowlands, Global Planet. Change, 7, 25-40, 1999.

Smith, H. J., Fischer, H., Wahlen, M., Mastroianni, D., and Deck, B.: Dual modes of the carbon cycle since the Last Glacial Maximum, Nature, 400, 248-250, 1999.

Stauffer, B., Blunier, T., Dallenbach, A., Indermühle, A., Schwander, J., Stocker, T. F., Tschumi, J., Chappellaz, J., Raynaud, D., Hammer, C. U., and Clausen, H. B.: Atmospheric $\mathrm{CO}_{2}$ concentration and millennial-scale climate change during the last glacial period, Nature, 392, 59-62, 1998.

Steffensen, J. P., Andersen, K. K., Bigler, M., Clausen, H. B., Dahl-Jensen, D., Fischer, H., Goto-Azuma, K., Hansson, M., Johnsen, S. J., Jouzel, J., Masson-Delmotte, V., Popp, T., Rasmussen, S. O., Rothlisberger, R., Ruth, U., Stauffer, B., SiggaardAndersen, M.-L., Sveinbjornsdottir, A. E., Svensson, A., and White, J. W. C.: High-Resolution Greenland Ice Core Data Show Abrupt Climate Change Happens in Few Years, Science, 321, 680-684, 2008.

Steinacher, M., Joos, F., Frölicher, T. L., Plattner, G.-K., and Doney, S. C.: Imminent ocean acidification in the Arctic projected with the NCAR global coupled carbon cycle-climate model, Biogeosciences, 6, 515-533, doi:10.5194/bg-6-515-2009, 2009.

Steinacher, M., Joos, F., Frölicher, T. L., Bopp, L., Cadule, P., Cocco, V., Doney, S. C., Gehlen, M., Lindsay, K., Moore, J. K., Schneider, B., and Segschneider, J.: Projected 21st century decrease in marine productivity: a multi-model analysis, Biogeosciences, 7, 979-1005, doi:10.5194/bg-7-979-2010, 2010.

Stocker, T. F.: Past and future reorganizations in the climate system, Quaternary Sci. Rev., 19, 301-319, 2000.

Stocker, T. F. and Johnsen, S. J.: A minimum thermodynamic model for the bipolar seesaw, Paleoceanography, 18, 1620-1635, 2003.

Stocker, T. F. and Marchal, O.: Abrupt climate change in the computer: Is it real?, P. Natl. Acad. Sci. USA, 97, 1362-1365, 2000. 
Stocker, T. F., Timmermann, A., Renold, M., and Timm, O.: Effects of Salt Compensation on the Climate Model Response in Simulations of Large Changes of the Atlantic Meridional Overturning Circulation, J. Climate, 20, 5912-5928, 2007.

Stouffer, R. J., Yin, J., Gregory, J. M., Dixon, K. W., Spelman, M. J., Hurlin, W., Weaver, A. J., Eby, M., Flato, G. M., and Hasumi, H.: Investigating the Causes of the Response of the Thermohaline Circulation to Past and Future Climate Changes, J. Climate, 19, 1365-1387, 2006.

Stouffer, R. J., Seidov, D., and Haupt, B. J.: Climate Response to External Sources of Freshwater: North Atlantic versus the Southern Ocean, J. Climate, 20, 436-448, 2007.

Timmermann, A., Gildor, H., Schulz, M., and Tziperman, E.: Coherent Resonant Millennial-Scale Climate Oscillations Triggered by Massive Meltwater Pulses, J. Climate, 16, 2569-2585, 2003.

Timmermann, A., An, S. I., Krebs, U., and Goosse, H.: ENSO Suppression due to Weakening of the North Atlantic Thermohaline Circulation, J. Climate, 18, 3122-3139, 2005.

Timmermann, A., Okumura, Y., An, S. I., Clement, A., Dong, B., Guilyardi, E., Hu, A., Jungclaus, J. H., Renold, M., Stocker, T. F., Stouffer, R. J., Sutton, R., Xie, S. P., and Yin, J.: The influence of a weakening of the Atlantic meridional overturning circulation on ENSO, J. Climate, 20, 4899-4919, 2007. van't Veer, R., Islebe, G. A., and Hooghiemstra, H.: Climatic Change during the Younger Dryas chron in northern South America: a test of the evidence, Quaternary Sci. Rev., 19, 1821-1835, 2000.

Vellinga, M. and Wood, R. A.: Global Climatic Impacts of a Collapse of the Atlantic Thermohaline Circulation, Climatic Change, 54, 251-267, 2002.

Voelker, A. H. L.: Global distribution of centennial-scale records for Marine Isotope Stage (MIS)3: a database, Quaternary Sci. Rev., 21, 1185-1212, 2002.

Wang, X., Auler, A. S., Edwards, R. L., Cheng, H., Cristalli, P. S., Smart, P. L., Richards, D. A., and Shen, C.: Wet periods in northeastern Brazil over the past $210 \mathrm{kyr}$ linked to distant climate anomalies, Nature, 432, 740-743, 2004.

Wang, X., Auler, A. S., Edwards, R. L., Cheng, H., Ito, E., Wang, Y., Kong, X., and Solheid, M.: Millennial-scale precipitation changes in southern Brazil over the past 90000 years, Geophys. Res. Lett., 34, L05708, doi:10.1029/2007GL031149, 2007.

Yu, Z. and Eicher, U.: Abrupt climate oscillations during the last deglaciation in Central North America, Science, 282, 22352238, 1998.

Zhang, R. and Delworth, T. L.: Simulated Tropical Response to a Substantial Weakening of the Atlantic Thermohaline Circulation, J. Climate, 18, 1853-1860, 2005. 